WORKING PAPER \#520

PRINCETON UNIVERSITY

INDUSTRIAL RELATIONS SECTION

July 2007

Revised: December 7, 2009

\title{
Job Loss and the Decline in Job Security in the United States *
}

\author{
Henry S. Farber \\ Princeton University \\ December 7, 2009
}

\begin{abstract}
Job tenure and the incidence of long-term employment have declined sharply in the United States However, rates of job loss as measured by the Displaced Workers Survey (DWS), while cyclical, have not shown a trend increase that would account for the decline in job tenure and long-term employment. This presents a puzzle that has several potential solutions. One is that, while overall rates of job loss have not increased, rates of job loss for high-tenure workers have increased relative to those for lower-tenure workers. Another is that there has been an increase in rates of job change that is not captured in the limited questions asked in the DWS. Some of this seemingly voluntary job change (e.g., the taking of an offered buy-out) may reflect the kind of worker displacement that the DWS was meant to capture but is not reported as such by workers.

In this study, I address these issues by 1) documenting the decline in job tenure and longterm employment using data from various supplements to the Current Population Survey (CPS) from 1973-2008, 2) documenting the lack of secular change in rates of job loss using data from the DWS from 1984-2008, and 3) exploring the extent to which the observed patterns result from a relative increase in rates of job loss among high-tenure workers. I find that the decline in job tenure and long-term employment is restricted to the private sector and that there has been some increase in job tenure and long-term employment in the public sector. I find no secular changes in relative rates of job loss in either sector that could account for these trends. Reconciliation of the trends in the tenure and displacement data must lie with a failure to identify all relevant displacement in the DWS.

\footnotetext{
*Industrial Relations Section, Firestone Library, Princeton University, Princeton, NJ 08544-2098. email: farber@princeton.edu. This paper was prepared for an NBER Conference on Research on Income and Wealth, "Labor in the New Economy," held November 16-17, 2007 in Bethesda, MD
} 


\section{Introduction}

There is ample evidence that long-term employment is on the decline in the United States. The common understanding that, after some turnover early in careers, most workers find a job (relationship with an employer) that lasts for a long period of time (a "life-time" job), has been challenged in the last fifteen to twenty years, both in academic research and in the media, as large corporations have engaged in highly publicized layoffs and the industrial structure of the U.S. economy has shifted in the face of global competitive pressures. However, there is little evidence that rates of job loss have increased. This leaves a puzzle regarding the mechanism through which long-term employment relationships are becoming less common.

One possible explanation is that there as been an increase in the rate of job change by workers that is not captured by the DWS. This could be in the form of voluntary job change. accounts for the decline in job durations. The interpretation what is a "job loss" and what is a "voluntary" job change is left to the respondent in the DWS. The result may be an underestimate of employer-initiated separations. For example, a firm may offer workers "buy-outs." Workers who take these buy-outs in lieu of a layoff may not report a job loss in the DWS. Unfortunately, there are no large-scale surveys that measure job change and reasons for job change generally.

Another possible explanation is that, while the overall rate of job loss has not increased, higher tenure workers have become more susceptible to job loss. I begin my analysis by examining the decline in job tenure and long-term employment separately in the private and public sectors using data from various supplements to the Current Population Survey (CPS) from 1973-2008, I find that the decline in measures of job security is confined to the private sector and that these measures of job security show an increase in the public sector. I then document the lack of secular change in rates of job loss in either sector using data from the Displaced Workers Surveys (DWS) from 1984-2008. Finally, I explore the extent to which the observed declines in job tenure and long-term employment in the private sector result from a relative increase in rates of job loss among high-tenure workers in the private sector. I find that these has been no such relative change and that reconciliation of the trends in the tenure and displacement data must lie with a failure to identify all relevant displacement in the DWS.

\section{Background and Earlier Literature}

The evolution of the job durations in the U.S. has played out in the context of dramatic growth in employment over the last 40 years. Civilian employment was 85.1 million in 
1973 and rose to 145.4 million in 2008. ${ }^{1}$ Thus, 60 million jobs have been created on net in the past 33 years, for an average rate of employment growth of 1.5 percent per year over this period. Despite this record of sustained growth in employment in the United States, there is longstanding concern that the quality of the stock of jobs in the economy more generally is deteriorating. The concern about job quality is based in part on the fact that the share of employment that is in manufacturing has been declining over a long period of time. $^{2}$ This has led to the view that, as high-quality manufacturing jobs are lost, perhaps to import competition, they are being replaced by low-quality service sector jobs (so-called hamburger-flipping jobs). The high-quality jobs are characterized by relatively high wages, full-time employment, substantial fringe benefits, and, perhaps most importantly, substantial job security (low rates of turnover). The low-quality jobs are characterized disproportionately by relatively low wages, part-time employment, an absence of fringe benefits, and low job security (high rates of turnover).

The perceived low quality of many newly-created jobs fuels the concern that the nature of the employment relationship in the United States is changing from one based on longterm full-time employment to one based on more short-term and casual employment is. There has been concern that employers are moving toward greater reliance on temporary workers, on subcontractors, and on part-time workers. Potential motivation for employers to implement such changes range from a need for added flexibility in the face of greater uncertainty regarding product demand to avoidance of increasingly expensive fringe benefits and long-term obligations to workers. The public's concern arises from of the belief that these changes result in lower quality (lower paying and less secure) jobs for the average worker.

\subsection{Literature on Job Stability}

There have been a series of analyses of job stability that have relied on mobility supplements to various January Current Population Surveys. An influential early analysis was carried out by Hall(1982). He used published tabulations from some of the early January mobility supplements to compute contemporaneous job retention rates. Hall found that, while any particular new job is unlikely to last a long time, a job that has already lasted five years has a substantial probability of lasting twenty years. He also finds that a substantial fraction of workers will be on a "lifetime" job (defined as lasting at least twenty years) at some point

1 These statistics are taken from U.S. Bureau of Labor Statistics Series ID LNU02000000. This is the civilian employment level derived from the Current Population Survey for workers aged 16 and older.

2 The manufacturing share of non-farm employment has been falling for over fifty years. Manufacturing's share was 30.9 percent in 1950 and fell to 9.8 percent in 2008. These statistics are taken from U.S. Bureau of Labor Statistics Series ID CEU00000001 and CEU30000001 derived from the Current Employment Statistics payroll data. 
in their life. Ureta (1992) used the January 1978, 1981, and 1983 mobility supplements to recompute retention rates using artificial cohorts rather than contemporaneous retention rates.

Several more recent papers have used CPS data on job tenure to examine changes in employment stability. Swinnerton and Wial (1995), using data from 1979 through 1991, analyzed job retention rates computed from artificial cohorts and conclude that there has been a secular decline in job stability in the 1980's. In contrast, Diebold, Neumark, and Polsky (1994), using CPS data on tenure from 1973 through 1991 to compute retention rates for artificial cohorts, found that aggregate retention rates were fairly stable over the 1980's but that retention rates declined for high school dropouts and for high school graduates relative to college graduates over this period. I interpret a direct exchange between Diebold, Polsky, and Neumark (1996) and Swinnerton and Wial (1996) as supporting the view that the period from 1979-91 is not a period of generally decreasing job stability. In Farber (1998), I used CPS data on job tenure from 1973 through 1993 and found that the prevalence of long-term employment has not declined over time but that the distribution of long jobs has shifted. I further found that less-educated men were less likely to hold long jobs than they were previously but that this is offset by a substantial increase in the rate at which women hold long jobs. More recently (Farber, 2000), I examined CPS data on job tenure from 1973 through 1996, and I found that the prevalence of long- term employment relationships among men declined by 1996 to its lowest level since 1979. In contrast, long-term employment relationships became somewhat more common among women.

Rose (1995) used data from the Panel Study of Income Dynamics (PSID) to measure job stability by examining the fraction of male workers who do not report any job changes in a given time period, typically ten years. Rose found that the fraction of workers who reported no job changes in given length of time was higher in the 1970's than in the 1980's. He argued that this is evidence of increasing instability of employment.

The Russell Sage Foundation sponsored a conference organized by David Neumark on "Changes in Job Stability and Job Security" in 1998. ${ }^{3}$ The evidence presented here is mixed regarding whether job tenure was declining. Jaeger and Stevens (1999) used data from the PSID and the CPS mobility and benefit supplements on (roughly) annual rates of job change to try to reconcile evidence from the CPS and PSID on job stability. They found no change in the share of males in short jobs and some decline between the late 1980s and mid-1990s in the share of males with at least ten years of tenure. ${ }^{4}$ Neumark, Polsky, and Hansen (1999) found a similar decline in long-term employment but concluded that this does not

\footnotetext{
3 The Proceedings of this conference are published in Neumark (2000), and a number of these papers are published in The Journal of Labor Economics Volume 17, Number 4, Part 2, October 1999

${ }^{4}$ Unfortunately, due to the design of the PSID, neither of these studies examined the mobility experience of women.
} 
reflect a secular trend. Gottschalk and Moffitt (1999) use monthly data from the Survey of Income and Program Participation (SIPP) along with annual data from the SIPP and the PSID, and they found no evidence of an upward trend in job insecurity in the 1980s and 1990s. Valletta (1999) used data from the PSID from 1976-1993 and found some decline in long-term employment relationships.

In more recent work, Stewart (2002) used data from the March CPS to investigate two aspects of job security. The first, the likelihood of leaving a job, showed no particular trend from 1975 through 2000 based on these data. The second, the likelihood of making an employment-to-employment transition, increased over this period while the likelihood of making an employment-to-unemployment transition decreased. Stewart concluded that the cost of changing jobs has decreased.

Stevens (2005) examined data from several longitudinal histories of older male workers (late 50s and early 60s) with regard to changes over time in the length of longest job held during careers. She found that there has been no change between the late 1960s and late early 2000s and concluded that there has not been a decline in the in the incidence of "lifetime jobs". A careful reading of her results show an increase in average longest tenure from about 22 years among older workers in 1969 to 24 years in 1980 followed by a decline to 21.4 years in 2002. A reasonable interpretation of this pattern is that the earliest cohorts had jobs interrupted by service in World War II, resulting in lower average longest tenure than subsequent cohorts. The decline since 1980 may then reflect a real decline in job durations. Additionally, the most recent cohort examined by Stevens was born in the 1940s so that her analysis cannot shed light on the experience of more recent birth cohorts.

In Farber (2007) I used data from 21 supplements to the Current Population Survey (CPS) over the 1973-2008 period that contain information on how long workers have been employed by their current firm. I found that, by virtually any measure, more recent cohorts of male workers have been with their current employers for less time at specific ages. I did not find a corresponding decline in age-specific tenure for women. This contrast reflects the increased commitment of women to the labor force tempered by the fact that many working women, when have young children, either exit the labor force for a period of time or change jobs to one with different or more flexible hours.

Taken as a whole, I conclude from this earlier literature that there has been a decline in job tenure and in the incidence of long-term employment relationships.

\section{$2.2 \quad$ Literature on Job Loss}

In an earlier paper (Farber 1993), I used the five DWSs from 1984 to 1992 to examine changes in the incidence and costs of job loss over the period from 1982-1991. I found that there were slightly elevated rates of job loss for older and more educated workers in the slack labor market in the latter part of the period compared with the slack labor market of the earlier 
part of the period. But I found that job loss rates for younger and less educated workers were substantially higher than those for older and more educated workers throughout the period. These findings are consistent with the long-standing view that younger and less educated workers bear the brunt of recessions. I also confirmed the conventional view that the probability of job loss declines substantially with tenure.

Gardner (1995) carried out the first analysis of which I am aware that incorporated the 1994 DWS. She examined the incidence of job loss from 1981-92. While she found roughly comparable overall rates of job loss in the 1981-82 and 1991-92 periods, she found that the industrial and occupational mix of job loss changed over this period. There was an decreased incidence of job loss among blue-collar workers and workers in manufacturing industries and an increase in job loss among white-collar workers and workers in non-manufacturing industries.

In another paper (Farber 1997), I used the seven DWSs from 1984 to 1996 to revisit the issue of changes in the incidence and costs of job loss. I found that the overall rate of job loss increased in the first half of the 1990s despite the sustained economic expansion. Hipple (1999) carried out the first analysis of the 1998 DWS, and he finds that the displacement rate among workers who had held their jobs for at least three years fell only slightly between the 1993-1994 period and the 1995-1996 period despite the sustained economic expansion.

There is a substantial literature using the DWS to study the post-displacement employment and earnings experience of displaced workers. ${ }^{5}$ This work demonstrates that displaced workers suffer substantial periods of unemployment and that earnings on jobs held after displacement are substantially lower than pre-displacement earnings. In my earlier work (Farber 1993), I found that there was no difference on average in the consequences of job loss between the 1982-83 recession and the the 1990-91 recession.

The earnings loss suffered by displaced workers is positively related to tenure on the pre-displacement job. On the other hand, Kletzer (1989) found further that the postdisplacement earnings level is positively related to pre-displacement tenure, suggesting that workers displaced from long jobs are more able on average than those displaced from shorter jobs. In more recent work, Neal (1995) using the DWS and Parent (1995) using the National Longitudinal Survey of Youth (NLSY) found that workers who find new employment in the same industry from which they were displaced earn more than do industry switchers. This work suggests that Kletzer's finding that post-displacement earnings are positively related to pre-displacement tenure may be a result of the transferability of industry-specific capital. Workers who are re-employed in the same industry "earn a return" on their previous tenure while those re-employed in a different industry do not.

In Farber (2004) I examined changes in the incidence and consequences of job loss between

${ }^{5}$ See, for example, Podgursky and Swaim (1987), Kletzer (1989), Topel (1990), Farber (1993), Farber (1997). 
1981 and 2001 using data from the Displaced Workers Surveys (DWS) from 1984-2002. I found that the overall rate of job loss has a strong counter-cyclical component but that the job loss rate was higher than might have been expected during the mid-1990's given the strong labor market during that period. I found substantial earnings declines for displaced workers relative to what they earned before displacement. Additionally, foregone earnings growth (the growth in earnings that would have occurred had the workers not been displaced), is an important part of the cost of job loss for re-employed full-time job losers. There is no evidence of a decline during the tight labor market of the 1990s in the earnings loss of displaced workers who were reemployed full-time. In fact, earnings losses of displaced workers have been increasing since the mid 1990s. In Farber (2005), I update my earlier work to include data on job loss through 2003. Not surprisingly, there were higher job loss rates and lower post-displacement reemployment probabilities during the recession of the early 2000s.

With regard to overall rates of job loss, this literature suggests that job loss rates have a strong cyclical component. However, aside from several years with unusually high job-loss rates in the mid-1990s, there has been no secular increase in rates of job loss.

\section{The Decline In Long-Term Employment}

In this section, I present evidence on job durations from a sample consisting of not-selfemployed workers aged 20-64 from the 21 CPS supplements covering the period from 1973 to 2008 . The sample contains 924,423 workers. ${ }^{6}$ Since the factors highlighted as potentially causing a decline in job security are directly relevant to the private sector and less relevant to the public sector, I present separate analyses of job tenure in the two sectors.

\subsection{Measuring the Change in Tenure Over Time}

I organize my analysis of changes over time in the distribution of job durations by examining age-specific values of various distributional measures of job tenure for each sampled year. No one statistic can completely characterize a distribution, and I focus on several measures here:

- Mean job tenure (years with the current employer). Note that this is not mean completed job duration since since the jobs sampled are still in progress.

- The age-specific probability that a worker reports being on their job at least ten years. Because younger workers cannot have accumulated substantial job tenure, I restrict

\footnotetext{
${ }^{6}$ These data are described in more detail in Appendix I.
} 
this analysis to workers at least 35 years of age, and I examine how these probabilities have changed over time.

- The age-specific probability that a worker reports being in their job at least twenty years. Because younger workers cannot have accumulated substantial job tenure, I restrict this analysis to workers 45 years of age and older

- The age-specific probability that a worker reports being their job for less than one year. This provides information on changes over time in the transition from the early job-shopping phase of a career to more stable longer-term employment relationships.

An important measurement issue is related to cyclical changes in the composition of the sample. It is clear that workers with little seniority are more likely than high-tenure workers to lose their jobs in downturns (Abraham and Medoff, 1984). Thus, we would expect that the incidence of long-term employment, as measured by the fraction of workers with tenure exceeding some threshold, to be counter-cyclical. Tight labor markets will lead the distribution of job durations to lie to the left of the distribution in slack labor markets, and these cyclical influences need to be kept in mind when interpreting the results.

\subsection{Mean Tenure}

Figure 1 contains separate plots by sex of mean tenure by age for three time periods covered by the data $(1973-83,1984-95,1996-2008) .{ }^{7}$ These figures show clearly that 1$)$ mean tenure is rising with age and 2) women have lower mean tenure than men after about age 30. With regard to shifts over time in the tenure distribution, age-specific mean tenure for males has declined substantially, particularly for older workers. For example mean tenure for males at age 50 declined from 13.6 years in the 1970 s to 11.8 years in the early 2000s. In contrast, age-specific mean tenure for older women has increased. Mean tenure for females at age 50 increased from 8.9 years in the 1970s to 9.7 years in the early 2000s. This reflects the increased attachment to the labor force of more recent cohorts of women.

Interestingly, the decline in mean tenure is restricted to the private sector, and mean tenure has increased in the public sector. Figure 2 contains separate plots by sector of mean tenure for males by age for the three time periods. These figures show clearly that 1) mean tenure is rising with age in both the public and private sectors. With regard to shifts over time in the tenure distribution, age-specific mean tenure for males employed in the private sector has declined substantially, particularly for older workers. For example, mean tenure for private sector males at age 50 declined from 13.5 years in the $1973-83$ period to 11.3 years in the 1996-2008 period. The pattern in the public sector is the opposite. For example, mean

\footnotetext{
${ }^{7}$ Means are calculated weighted by CPS final sample weights.
} 

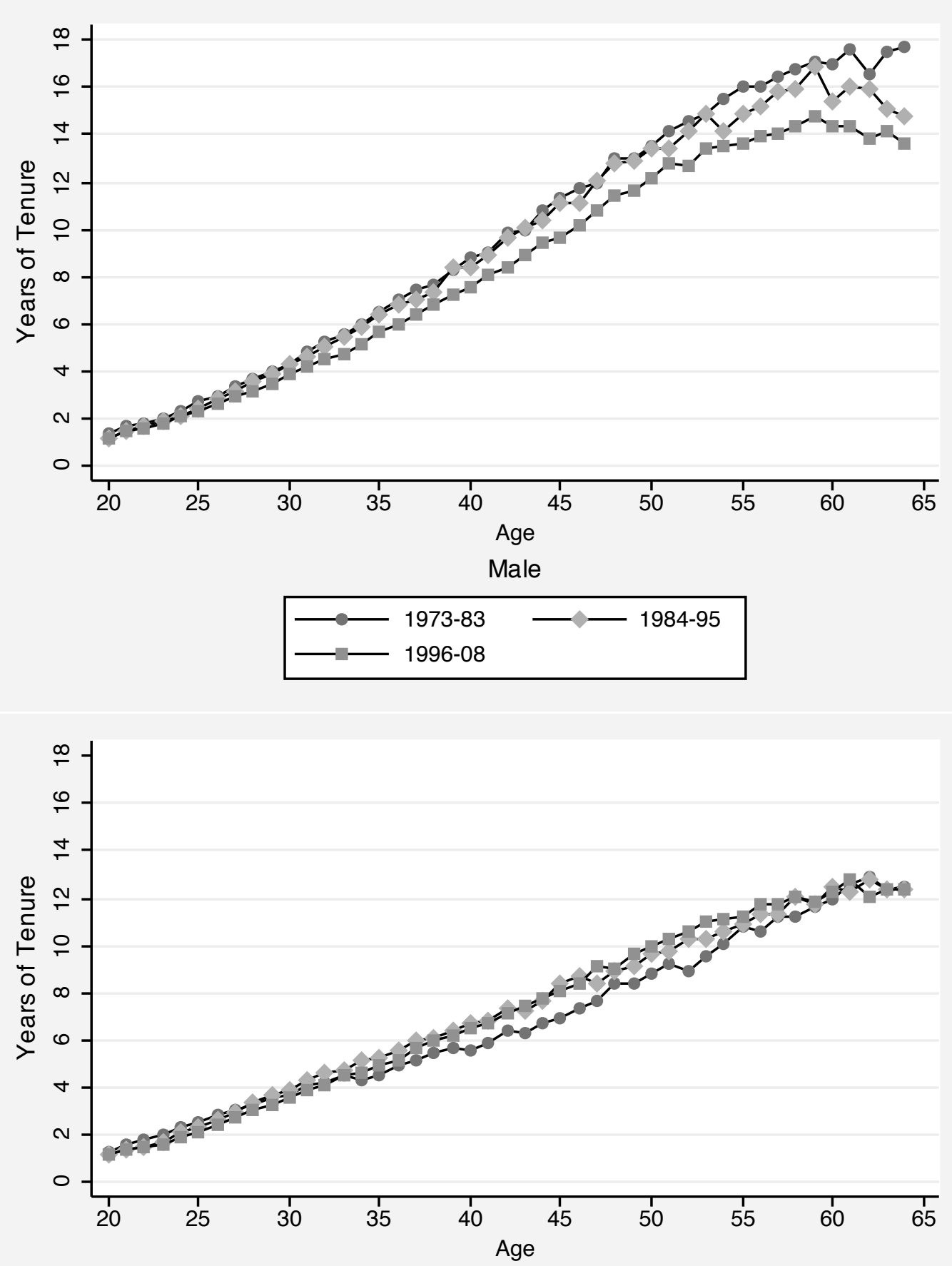

Female

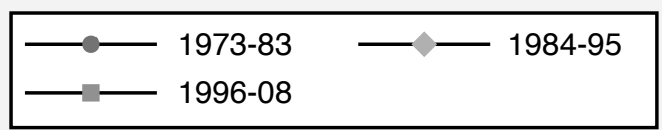

Figure 1: Mean Tenure, by Sex, Age, and Year 

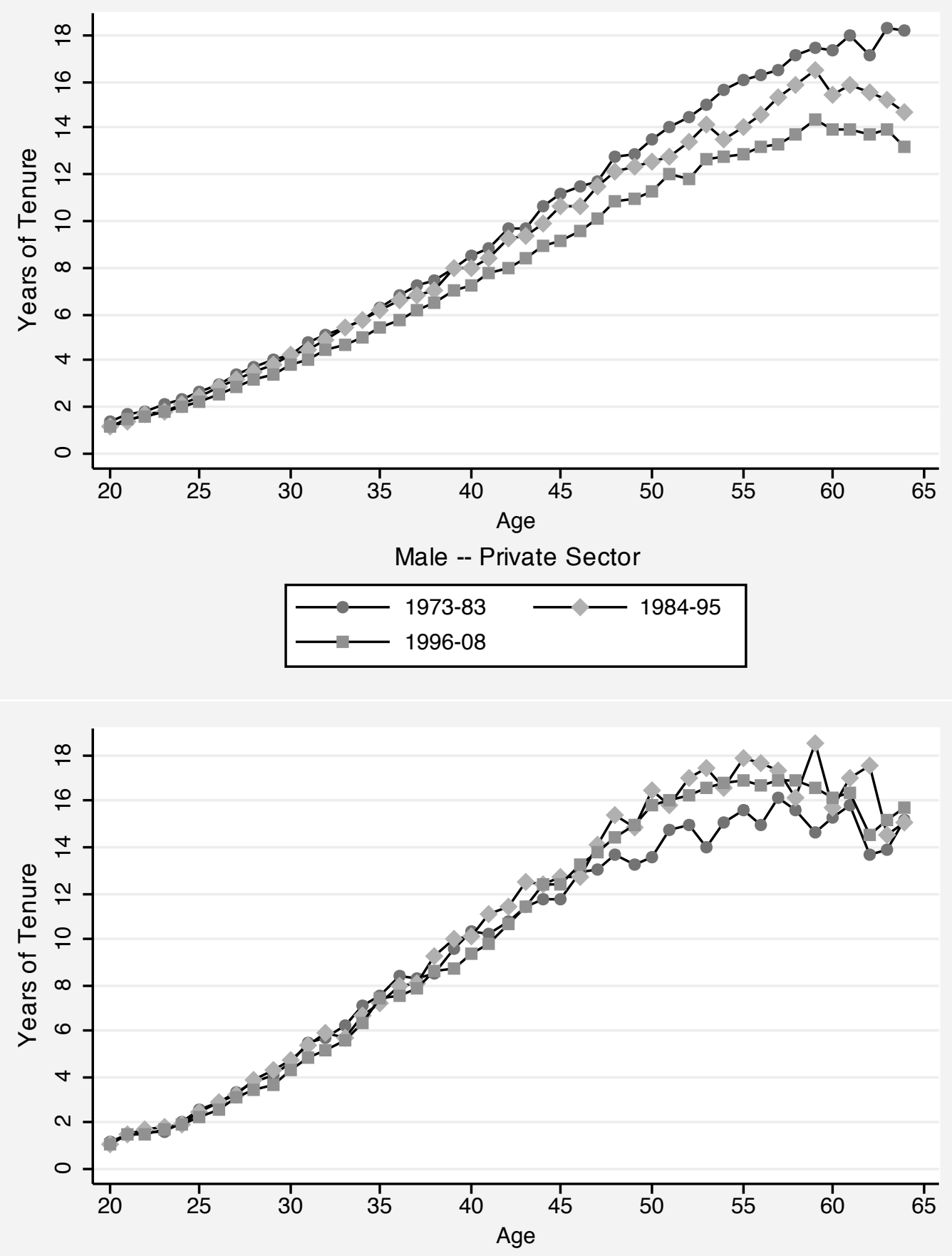

Male -- Public Sector

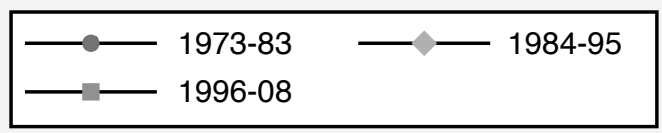

Figure 2: Mean Tenure for Males, by Sex, Age, and Year 
tenure for public sector males at age 50 increased from 13.6 years in the $1973-83$ period to 15.8 years in the $1996-2008$ period.

Figure 3 contains the same plots for females, and the pattern in the private sector is quite different than that for males. While mean tenure for females in increasing with age, tenure levels are substantially lower than those for males in the private sector. Importantly, there appears to have been no change in age-specific job tenure for females employed in the private sector. This is despite the well-documented increase in female attachment to the labor force. In contrast, females in the public sector have seen a substantial increase in mean job tenure. For example, mean tenure for public sector females at age 50 increased from 9.3 years in the 1973-83 period to 12.8 years in the 1996-2008 period. One explanation for this pattern may be that the economy-wide changes that the increase in female labor force attachment in the last thirty years have been offset in the private sector by the same forces that have led to the decline in male tenure in the private sector.

Another approach to summarizing the data is to estimate a linear model of the natural logarithm of tenure of the form

$$
\ln \left(T_{i j t}\right)=Y_{t}+A_{j}+\epsilon_{i j t},
$$

where $T_{i j t}$ is tenure in years for individual $i$ at age $j$ in year $t, Y_{t}$ is a calendar year indicator, and $A_{j}$ is a years-of-age indicator. This logarithmic specification embodies the plausible implicit assumption that proportional year effects on mean tenure are constant across ages and, equivalently, that the proportional age effects on mean tenure are constant across years. ${ }^{8}$ A more detailed investigation would allow for year effects that vary by age since changes in job security could express themselves differentially at various ages. However, the model in equation 3.1 fits the data quite well, and it serves as a good summary of the data. ${ }^{9}$

I estimate the model in equation 3.1 separately for men and women in the private and public sectors using ordinary least squares (OLS), weighted by the CPS final sample weights. The estimated year effects on mean tenure, normalized at zero in 1973, are converted to proportional differences in mean tenure relative to 1973 as $\exp \left(\hat{Y}_{t}-\hat{Y}_{1973}\right)-1$. These proportional differences are plotted in figure 4.

The patterns are quite different for the four groups of workers. There is a sharp decline of about 25 percent in age-specific mean tenure for male private-sector workers between the

\footnotetext{
${ }^{8}$ I do not estimate this model using absolute tenure because the implicit assumption in that case would be that absolute year effects on mean tenure are constant across ages and, equivalently, that absolute age effects on mean tenure are constant across years. This is clearly not plausible on inspection of figure 1, given the fact that younger workers have very low levels of tenure.

${ }^{9}$ I computed (separately for each of the four groups defined by sex and sector of employment) weighted mean tenure for each age/year combination and regressed these measures on a complete set of age and year fixed effects. This is essentially the main-effects model in equation 3.1 aggregated to the cell level. The $\mathrm{R}$-squareds from these regressions are all in excess of 0.95 .
} 


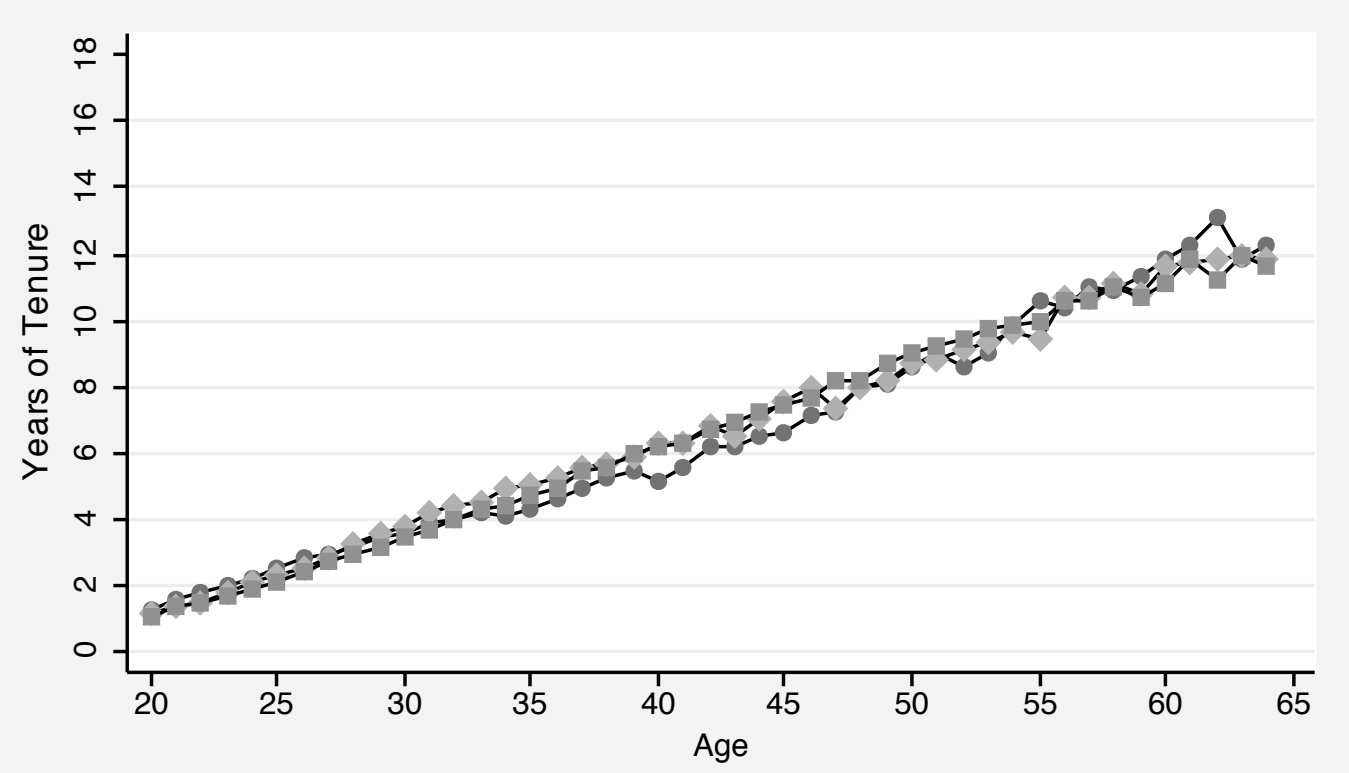

Female -- Private Sector
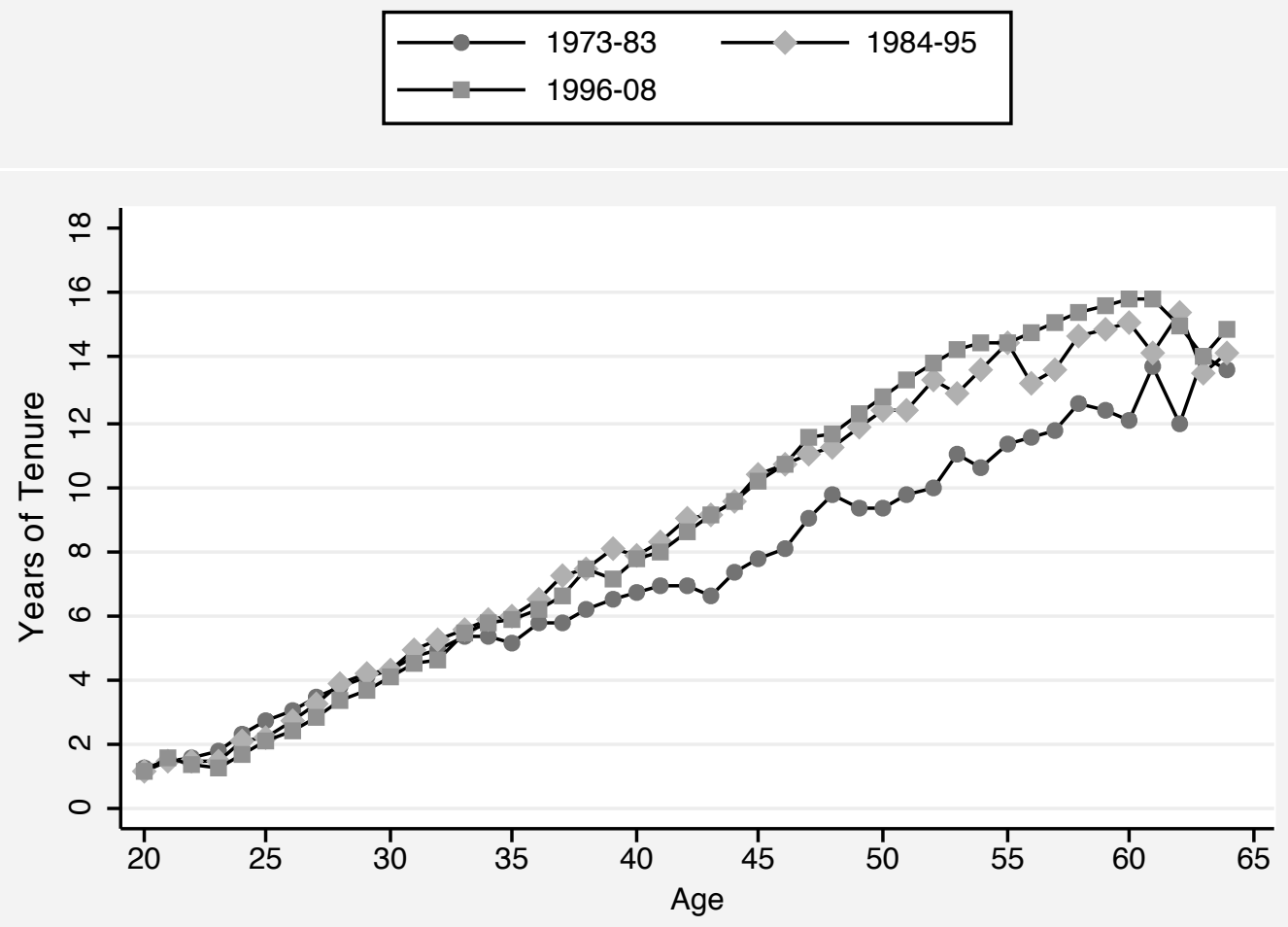

Female -- Public Sector

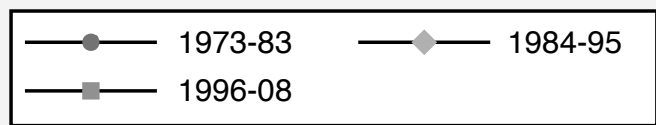

Figure 3: Mean Tenure for Females, by Sex, Age, and Year 


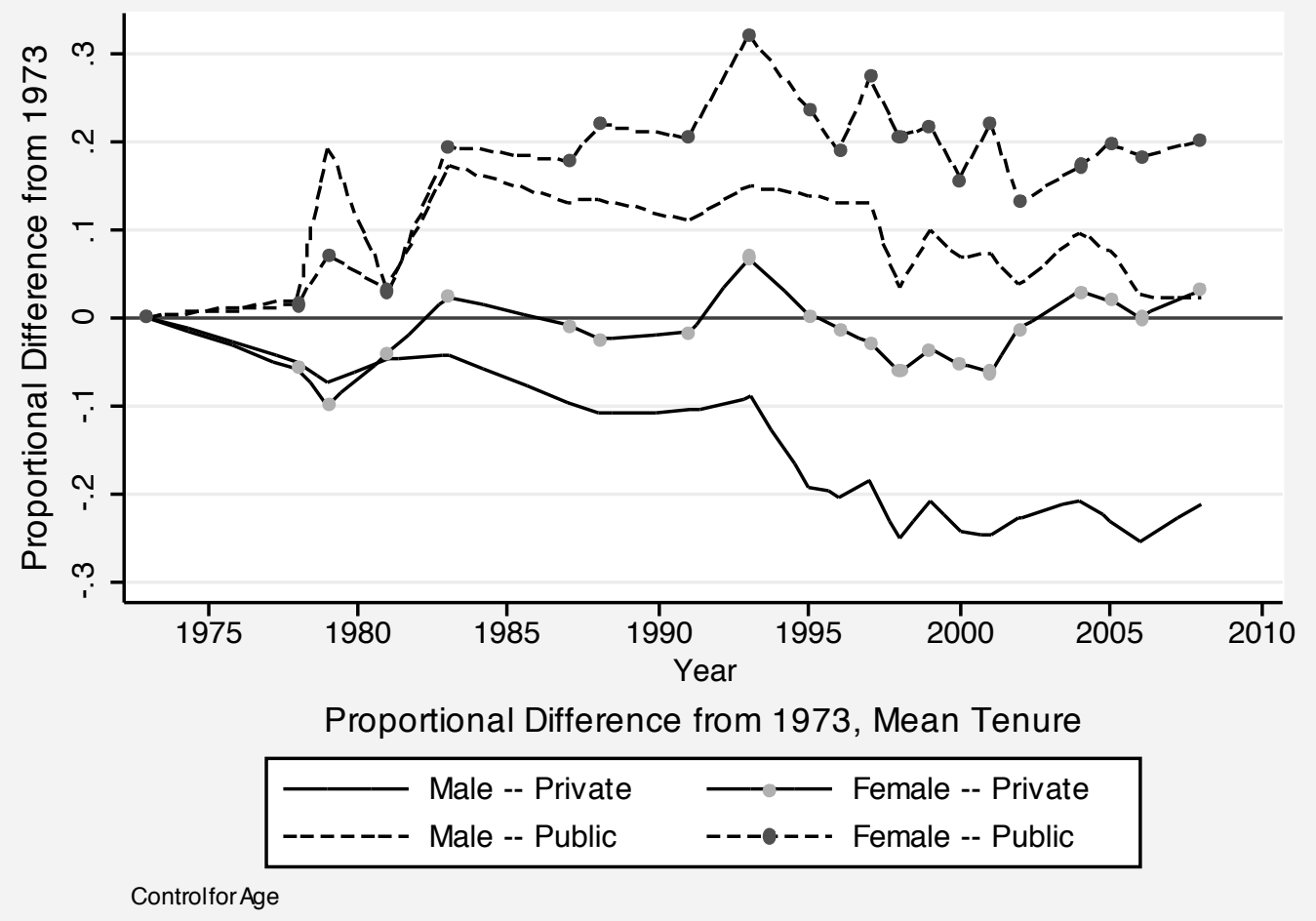

Figure 4: Proportional Difference from 1973, Mean Tenure, Controlling for Age.

1973 and 2008. In contrast, there is no systematic change over time in age-specific mean tenure for female private-sector workers. The public sector shows a dramatic increase in agespecific mean tenure both for men and for women over the sample period. Tenure for males in the public sector increased by about 18 percent between 1973 and 1983 before declining somewhat by 2008 to approximately the 1973 level. Age-specific mean tenure for females in the public sector was 30 percent higher in the early 1990s than in 1973 and remained about 20 percent higher in 2008 then it was in 1973.

These patterns are consistent with those found in figures 2 and 3 . They suggest a decline in long-term employment opportunities in the private sector that is most evident for males and is offset to some extent for females by their increased attachment to the labor force. The increase in mean tenure in the public sector could reflect an increase in the relative attractiveness of public sector jobs that is reinforced for females by their increased attachment to the labor force.

In addition to the increased presence of women in the labor force, there are other important changes that could be related to the decline in tenure. First is the well-known large increase in average educational attainment during the 20th century. While there is not a 


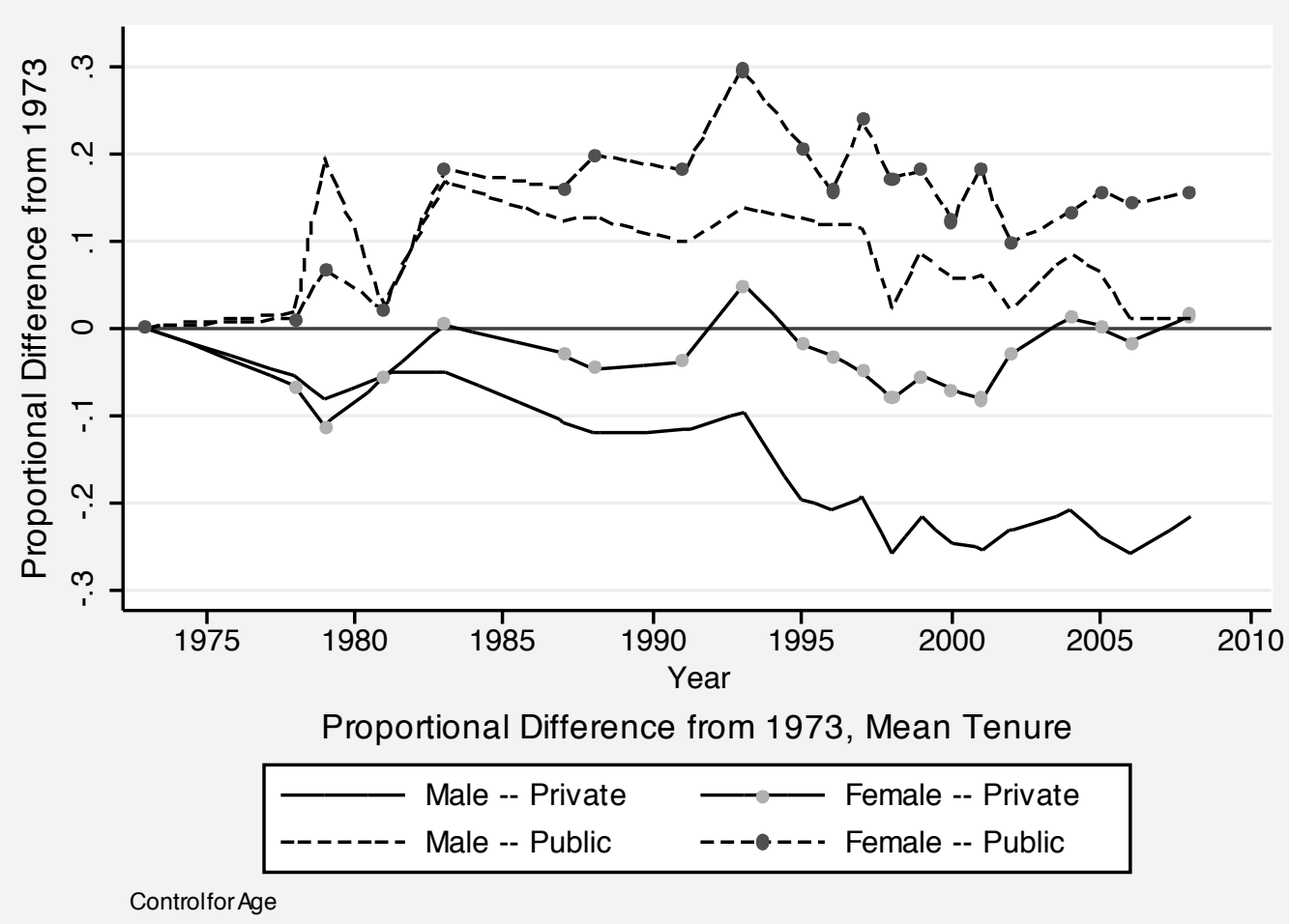

Figure 5: Proportional Difference from 1973, Mean Tenure. Controls for Age and Education.

clear relationship between educational attainment and tenure, I investigate how the decline in mean job tenure is related to the general increase in educational attainment. ${ }^{10}$

In order to provide a summary across educational categories of the proportional change in mean tenure over time accounting for changes in the educational distribution over time, I estimate, separately by sex and sector, an augmented version of the regression model for mean tenure in equation 3.1 as

$$
\ln \left(T_{i j t}\right)=E D_{i} \gamma+Y_{t}+A_{j}+\epsilon_{i j t},
$$

where $E D_{i}$ is a vector of dummy variables indicating educational attainment and $\gamma$ is a vector of associated coefficients. The estimated proportional change in mean tenure relative to $1973\left(\exp \left(\hat{Y}_{t}-\hat{Y}_{1973}\right)-1\right)$ are plotted in figure 5, and they are very similar in shape to those derived without controlling for education (figure 4).

A second and potentially more important factor that could account for the decline in tenure is the increased presence of immigrants in the U.S. labor force. By definition, newly

${ }_{10}$ Mean tenure in my analysis sample for each of the four educational categories are $\mathrm{ED}<12: 7.2$ years, $\mathrm{ED}=12$ : 7.3 years, ED 13-15: 6.5 years, and $\mathrm{ED} \geq 16: 7.4$ years. 
Table 1: Proportion Immigrants by Race and Hispanic Ethnicity, 1995-2008

\begin{tabular}{r|c|rrrrr} 
Year & All & $\begin{array}{c}\text { White } \\
\text { NonHisp }\end{array}$ & $\begin{array}{r}\text { Nonwhite } \\
\text { NonHisp }\end{array}$ & $\begin{array}{c}\text { All } \\
\text { Hisp }\end{array}$ & $\begin{array}{c}\text { White } \\
\text { Hisp }\end{array}$ & $\begin{array}{c}\text { Nonwhite } \\
\text { Hisp }\end{array}$ \\
\hline 1995 & 0.095 & 0.030 & 0.187 & 0.506 & 0.509 & 0.492 \\
1996 & 0.100 & 0.032 & 0.226 & 0.494 & 0.493 & 0.510 \\
1997 & 0.109 & 0.032 & 0.232 & 0.516 & 0.518 & 0.484 \\
1998 & 0.117 & 0.035 & 0.240 & 0.517 & 0.516 & 0.526 \\
1999 & 0.111 & 0.033 & 0.222 & 0.495 & 0.498 & 0.448 \\
2000 & 0.121 & 0.038 & 0.239 & 0.517 & 0.514 & 0.585 \\
2001 & 0.129 & 0.039 & 0.261 & 0.522 & 0.520 & 0.557 \\
2002 & 0.130 & 0.040 & 0.270 & 0.528 & 0.527 & 0.543 \\
2004 & 0.142 & 0.042 & 0.280 & 0.531 & 0.538 & 0.439 \\
2005 & 0.141 & 0.037 & 0.275 & 0.538 & 0.545 & 0.439 \\
2006 & 0.147 & 0.039 & 0.282 & 0.550 & 0.556 & 0.469 \\
2008 & 0.151 & 0.041 & 0.302 & 0.533 & 0.541 & 0.438 \\
\hline All & 0.125 & 0.037 & 0.254 & 0.523 & 0.526 & 0.484
\end{tabular}

Note: Based on data for not self employed workers 20-64 years of age from 11 CPSs covering the period from 1995 to 2008. Weighted by CPS final sample weights. $\mathrm{N}=515,759$.

arrived immigrants cannot have substantial tenure. Data on immigration are not available in any CPS with tenure data prior to 1995. Analysis of the data since 1995 illustrates both the sharp increase in immigrant share in the labor force and the fact that immigrants have lower job tenure than natives. The weighted immigrant fraction of the labor force in my sample increased steadily from 9.45 percent in 1995 to 15.1 percent in 2008. On average between 1995 and 2008, immigrants had 2.08 years lower tenure than natives (s.e. $=0.032$ ). Immigrants were only slightly younger than natives over the same period (average difference $=0.927$ years $($ s.e. $=0.048)) \cdot{ }^{11}$

An important question is how much of the decline in observed tenure since 1973 is due to the increased immigrant presence in the labor force. While not directly observable prior to 1995, immigrant status is strongly correlated with race and Hispanic ethnicity, which is observed in all years. Table 1 contains the immigrant proportion by race and Hispanic ethnicity for the 1995-2008 CPS data. The overall immigrant proportion of workers rose from 9.5 percent in 1995 to 15.1 percent in 2008. These immigrants are highly concentrated among nonwhites and Hispanics. Only 3.6 percent of white non-Hispanics are immigrants, while over fifty percent of Hispanics (white and nonwhite) are immigrants. ${ }^{12}$ Additionally, a growing fraction of nonwhite non-Hispanics are immigrants, rising from 18.7 percent in

\footnotetext{
${ }^{11}$ See Farber (2007) for a detailed analysis of the change in job tenure since 1995 that controls directly for immigrant status.

12 The rather sharp drop in the immigrant proportion among nonwhite Hispanics is due to the change in the race identification coding in the CPS in 2004.
} 
1995 to 30.2 percent in 2008. The rising overall immigrant share over this period is reflected in the growing share of Hispanics and nonwhites in the labor force. The Hispanic share of employment in my sample increased from 9.0 percent in 1995 to 13.5 percent in 2008 and the nonwhite share of employment increased from 15.2 percent to 17.7 percent over the same period.

Consistent with the upward trend in immigration and the decline in job tenure in the private sector is the fact that immigrants are disproportionately employed in the private sector. Fully 91.3 percent of immigrants are employed in the private sector between 1995 and 2008. In contrast, over the same period, only 81.9 percent of natives are employed in the private sector. These distributions are fairly constant over the period, implying that the increase in immigrant share of the total labor force could account for at least part of the private/public difference in the trends in job tenure.

In order to account, at least partly, for the role of increased immigration in the decline in tenure, I estimate age-specific proportional differences in mean tenure relative to 1973 controlling for race, Hispanic ethnicity and their interaction as well as age and education. I derive the year effects by estimating

$$
\ln \left(T_{i j t}\right)=\alpha_{1} N W_{i}+\alpha_{2} H_{i}+\alpha_{3} H_{i} N W_{i}+E D_{i} \gamma+Y_{t}+A_{j}+\epsilon_{i j t},
$$

where $N W_{i}$ is an indicator for nonwhite, $H_{i}$ is an indicator for Hispanic ethnicity, and $E D_{i}$ is a vector of indicators for four educational categories.

Figure 6 contains separate plots for males and females in the private and public sectors of the proportional differences from 1973 in mean tenure based on equation 3.3. The time-series patterns controlling for age, education, race, and ethnicity are similar to those controlling for age alone. The additional controls account for about 20 percent of the decline evident in figure 4.

There remains a sharp decline of about 20 percent in age-specific mean tenure for male private-sector workers between the 1973 and 2008, and there is still no systematic change over time in age-specific mean tenure for female private-sector workers. The public sector continues to show an increase in age-specific mean tenure both for men and for women over the sample period. Tenure for males in the public sector increased by about 18 percent between 1973 and 1983 before declining somewhat by 2008 to approximately the 1973 level. Age-specific mean tenure for females in the public sector was 30 percent higher in the early 1990s than in 1973 and remained about 15 percent higher in 2008 then it was in 1973.

It is clear from the analysis in this sub-section that age-specific mean tenure has declined dramatically over time and that only one about 20 percent of this decline can be accounted for by the sharp growth in immigrants in the labor market. This decline is concentrated among men in the private sector. Mean tenure increased for both men and women in the public sector. 


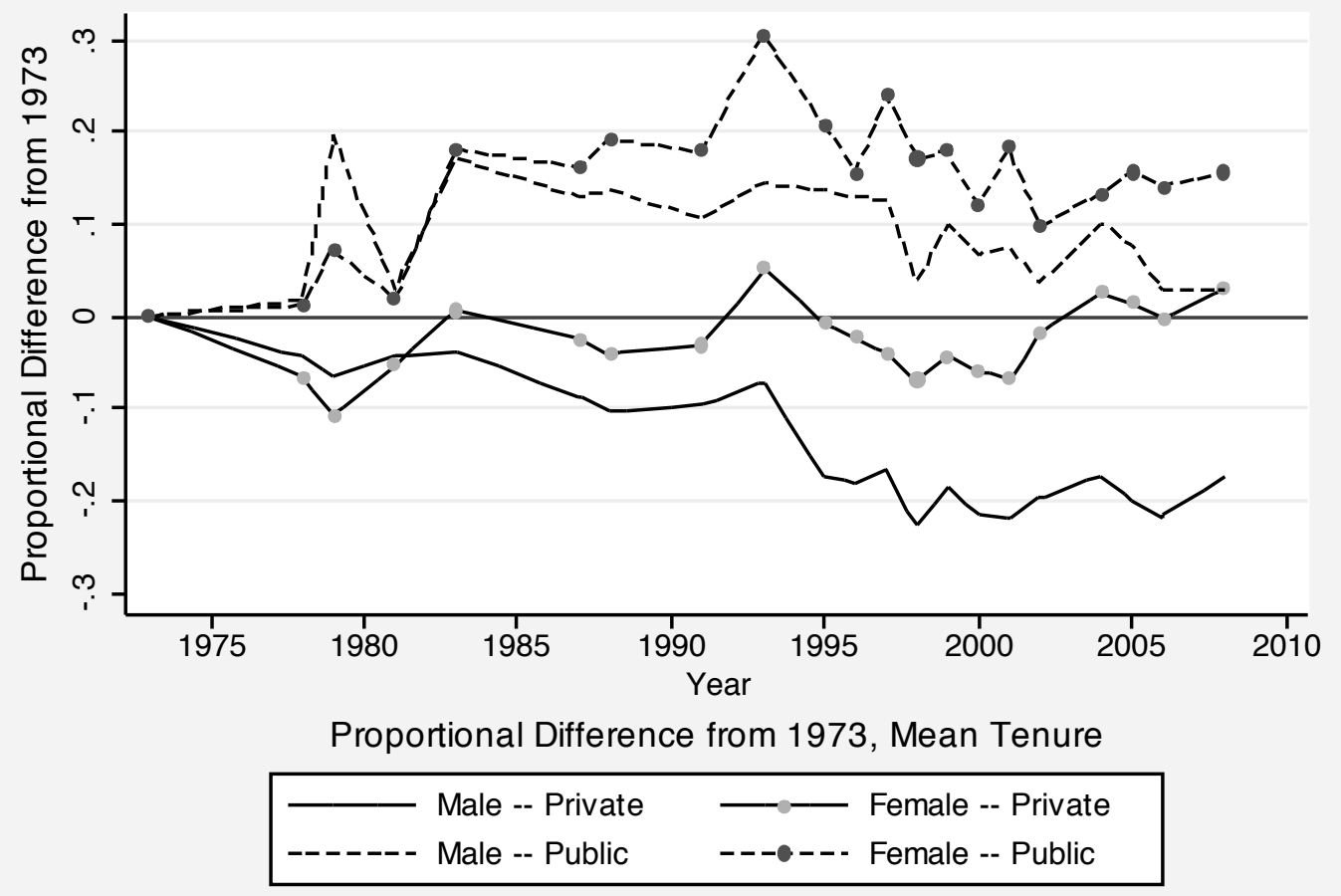

Controlsfor Age, Education, Race, and Hispanic Ethnicity

Figure 6: Proportional Difference from 1973, Mean Tenure. Controlling for Age, Education, Race, and Hispanic Ethnicity.

\subsection{Long-Term Employment}

Long-term employment is common in the U.S. Labor Market. In this analysis I consider two measures of long-term employment:

- the fraction of workers aged 35-64 who have been with their employer at least ten years (the "10-year rate"), and

- the fraction of workers aged 45-64 who have been with their employer at least twenty years (the "20-year rate").

Figure 7 contains plots of these two measures over the 1973-2008 period for men and women in the public and private sectors. It is clear that the incidence of long-term employment has declined dramatically for men employed in the private sector, with the 10-year rate falling from about 50 percent to about 37 percent and the 20-year rate falling from about 35 percent to about 22 percent between 1973 and 2008. In contrast, the incidence of long-term employment for men employed in the public sector increased over the same period, with the 

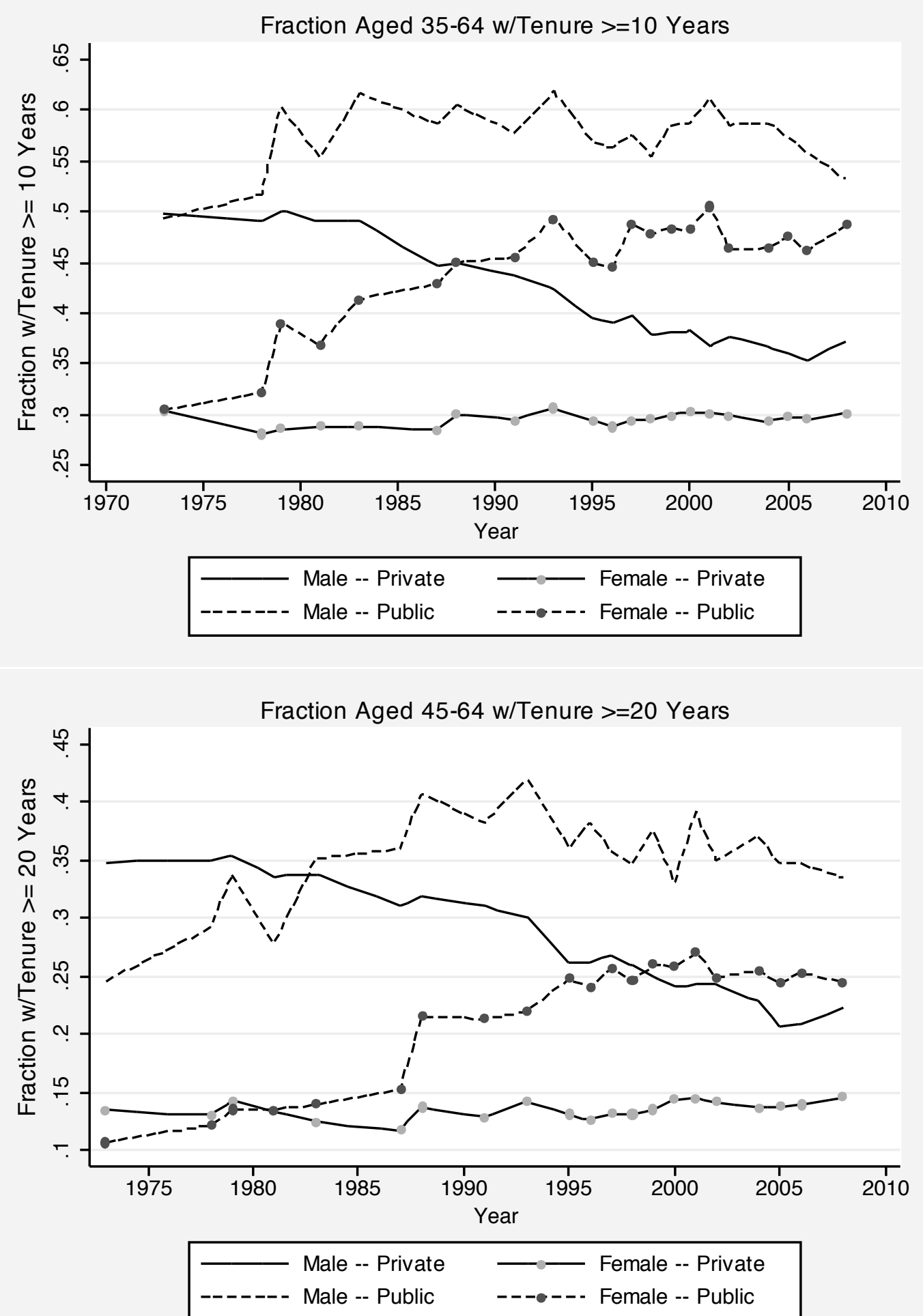

Figure 7: Fraction of Workers in Long Term Jobs, by Year. 
10-year rate increasing from 50 percent to 60 percent in 2000 before falling to 54 percent in 2008. Over the same period the 20-year rate for men employed in the public sector increased from 25 percent in 1973 to 40 percent in 1990 before falling off to 34 percent by 2008 .

The incidence of long-term employment among women employed in the private sector remained steady between 1973 and 2008, at a ten-year rate of about 30 percent and a twentyyear rate of about 15 percent. In sharp contrast, the incidence of long-term employment among women employed in the public sector increased substantially, with the ten-year rate increasing from 30 percent in 1973 to 45 percent in 2008 and the twenty-year rate increasing from 10 percent to 25 percent over the same period.

Because these measures are sensitive to the age distribution and other observable characteristics, I estimate age-specific year effects using the same approach I used for mean tenure. I estimate linear probability models using the same specification of explanatory variables (year, age, education, race, Hispanic ethnicity and the interaction of race and Hispanic ethnicity) in equation 3.3, and I report the estimated year effects (differences from 1973) from this analysis in figure 8.

Figure 8 contains separate plots for males and females by sector of employment of the year effects $(1973=0)$ for the 10 -year rate (top panel) and the 20 -year rate (bottom panel). The age-specific probability that a male worker in the private sector has been with his employer for at least ten years decreased steadily by about 10 percentage points. A decline of the same magnitude is also found for the 20-year rate for private-sector male workers. These 10 percentage points declines are substantial given the 1973 base ten-year rate of 50 percent and the base twenty-year rate of 35 percent (figure 7 ). The rates of long-term employment for females employed in the private sector show no change between 1973 and 2008.

As with the simple means in figure 7 , the long-term employment rates for both men and women employed in the public sector have increased since 1973. The increase has been particularly sharp for women, with both the ten- and twenty year rates increasing by more than 10 percentage points (from a 1973 base of 30 percent and 10 percent respectively).

Taken together, the analysis of the changes in average tenure (figure 6) and in the likelihood of long-term employment (figure 8) across cohorts shows clearly that average tenure has declined and long-term employment has become much less common for males in the private sector. Among females in the private sector, average tenure tenure and the incidence of longterm employment have remained steady. Workers in the public sector, on the other hand, have seen an increase in both average tenure and the incidence of long-term employment.

The difference in patterns between males and females in the private sector likely reflects the common factors reducing tenure for all workers offset for females by their dramatically increased attachment to the labor force over the past half century. This increase in attachment is also reflected in the larger increase in tenure and long-term employment among women relative to men in the public sector. 


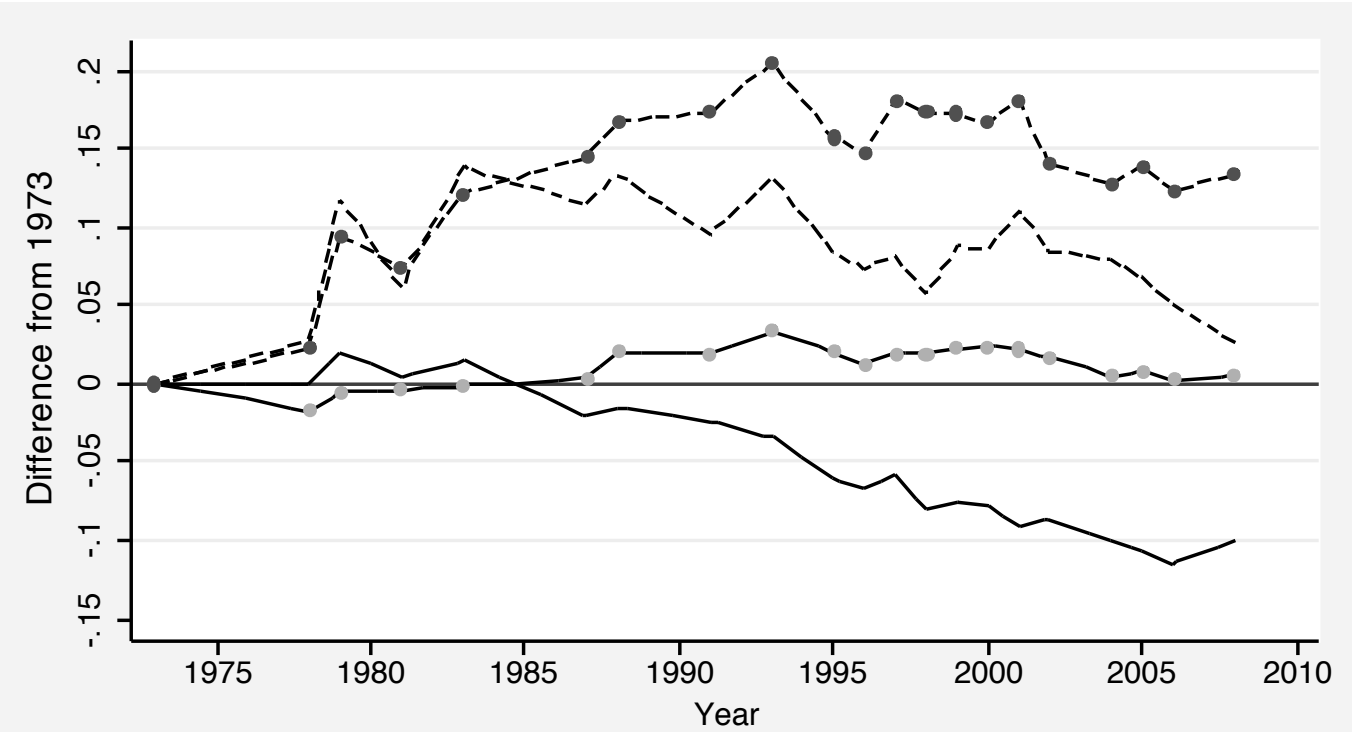

Difference from 1973, $\operatorname{Pr}($ Tenure $>=10$ years)

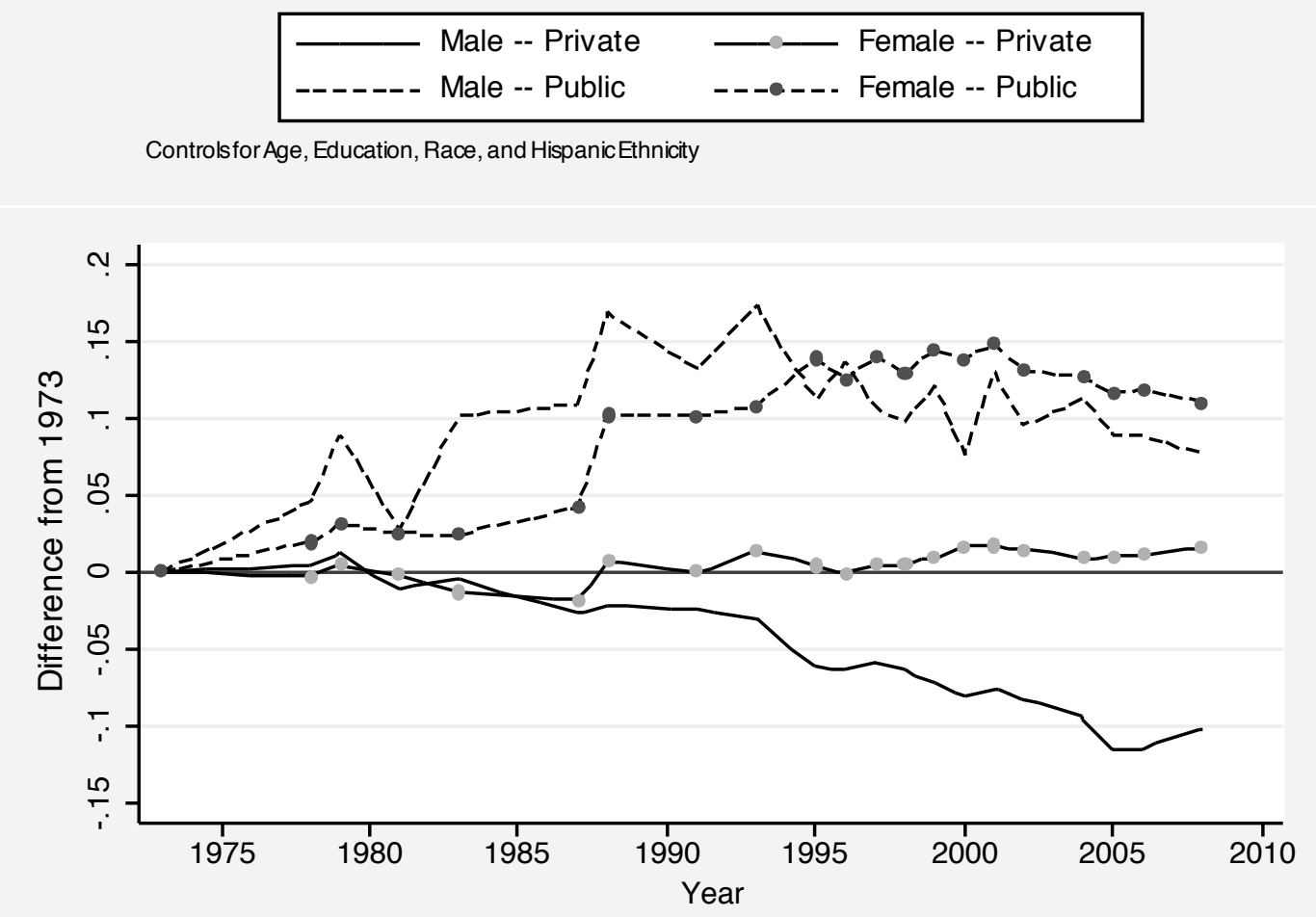

Difference from 1973, $\operatorname{Pr}($ Tenure $>=20$ years $)$

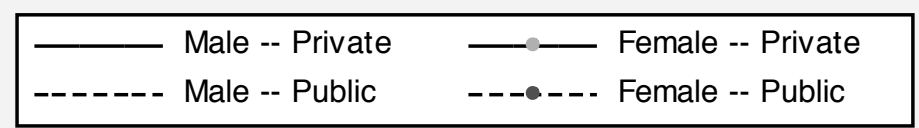

Controlsfor Age, Education, Race, and Hispanic Ethnicity

Figure 8: Proportional Difference from 1973, $\operatorname{Pr}(T \geq 10)$ and $\operatorname{Pr}(T \geq 20)$. Controlling for Age, Education, Race, and Hispanic Ethnicity. 
Table 2: New Job Rate, by Sex and Sector of Employment, 1973-2008

\begin{tabular}{r|cccc|c} 
& Male & Female & Male & Female & \\
Age & Private & Private & Public & Public & All \\
\hline $20-29$ & 0.339 & 0.371 & 0.281 & 0.314 & 0.347 \\
$30-39$ & 0.174 & 0.216 & 0.089 & 0.147 & 0.180 \\
$40-49$ & 0.122 & 0.154 & 0.056 & 0.084 & 0.123 \\
$50-59$ & 0.093 & 0.112 & 0.043 & 0.053 & 0.089 \\
$60-64$ & 0.080 & 0.089 & 0.052 & 0.041 & 0.076 \\
\hline All & 0.188 & 0.221 & 0.100 & 0.133 & 0.188
\end{tabular}

Note: The new job rate is the fraction of workers reporting less than one year of tenure with their current employer. Based on data for not self employed workers 20-64 years of age from 19 CPSs covering the period from 1973 to 2008. Weighted by CPS final sample weights. N=924,423.

A key conclusion is that the structure of employment in the private sector in the United States has become less oriented toward long-term jobs. Since public-sector employment as a fraction of total employment has remained steady at about 18 to 20 percent and seems unlikely to increase, it appears that young workers today will be less likely than their parents to have a "life-time" job.

\subsection{Churning: Are There More Very Short Jobs?}

The opposite but related pole of the job tenure distribution is short-term jobs. In Farber (1994, 1999), I present evidence that half of all new jobs (worker-employer matches) end within the first year. As I show below, a substantial fraction (around 20 percent) of all jobs have current tenure less than one year ("new jobs"). Not surprisingly, young workers are more likely than older workers to be in new jobs. High rates of job change among young workers are a natural result of search for a good job or a good match. ${ }^{13}$

Table 2 contains the new-job rate by ten-year age group for males and females by sector of employment. This illustrates the sharp decline in the new-job rate as workers age through their twenties especially and into their thirties. This decline is sharper for males, and the new-job rate is slightly higher for females in all age groups. This reflects the fact that females are more likely to leave and re-enter the labor force in mid-career.

In order to investigate how the new-job rate has changed over time, figure 9 contains plots of the new-job rate by year for each of the four sex/sector groups. In the private

\footnotetext{
${ }^{13}$ Burdett (1978) presents a model of job search with this implication. Jovanovic (1979) presents model of matching in the labor market with the same implication.
} 


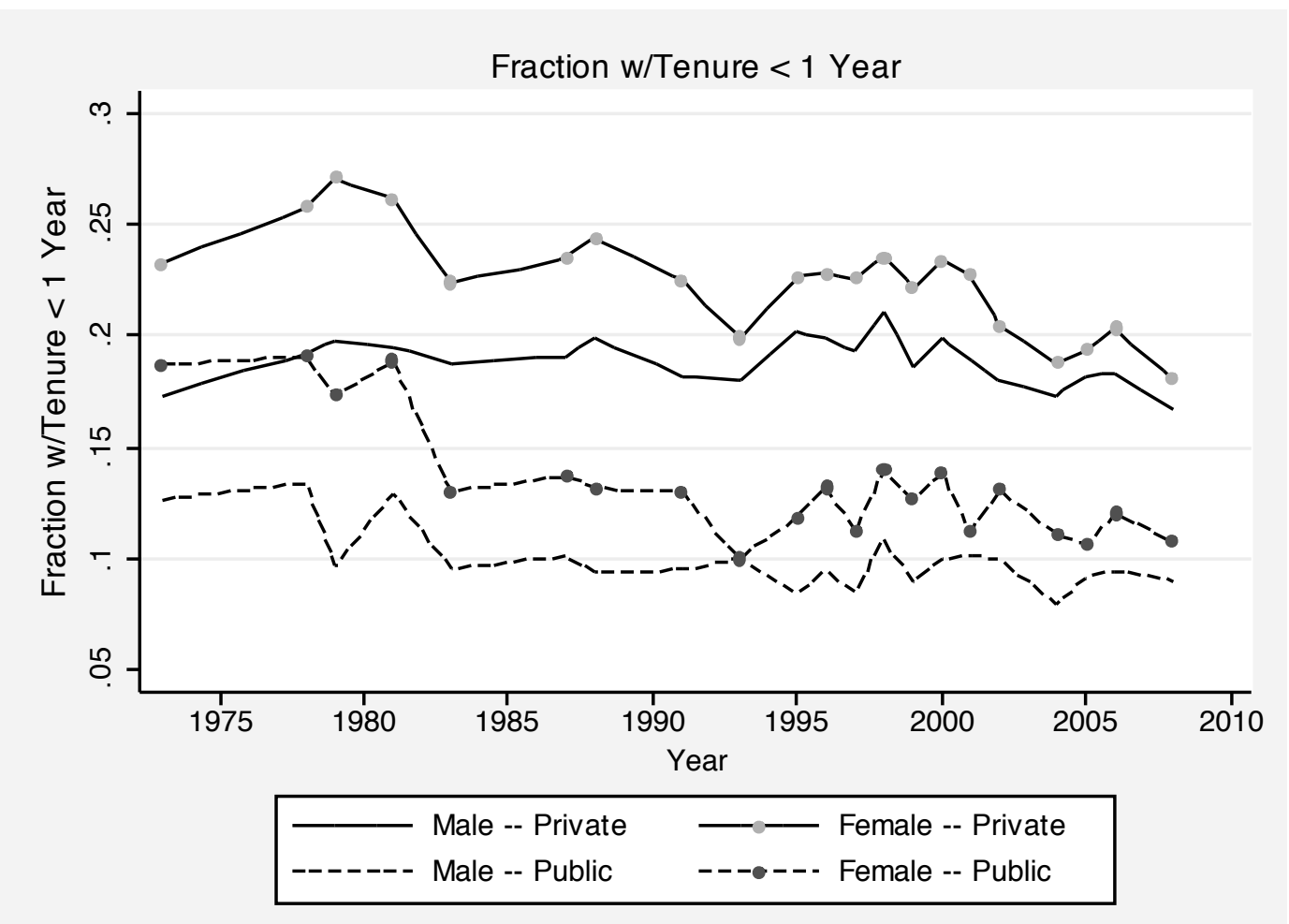

Figure 9: Fraction in New Jobs $(T<1$ Year $)$

sector, the new job rate decreased fairly steadily for females and decreased for males since the late 1990s. In the public sector, the new-job rate decreased quite sharply for females and generally been steady for males.

In order to account for differences by age and other characteristics, I estimate age-specific year effects using the same approach I used for means and for the probability of long-term employment. I estimate linear probability models of the probability of being in a new job using the same specification of explanatory variables (year, age, education, race, Hispanic ethnicity) in equation 3.3. Figure 10 contains separate plots by sector for males and females of the difference by year in the new-job rate relative to 1973 .

There is substantial variation over time in all four series, and it is difficult to pick out clear patterns. The new-job rate for private sector males is generally higher than in 1973 but has declined in recent rates to almost the 1973 level. The new-job rate for private sector females is about 2 percent points lower today than in 1973. The new-job rates in the public sector are generally lower than in 1973 for both males and females. The male rate fell particularly sharply in the 1980s and 1990s before recovering almost to the 1973 level.

The inverse relationship between the new-job rate and age evident in table 2 raises two 


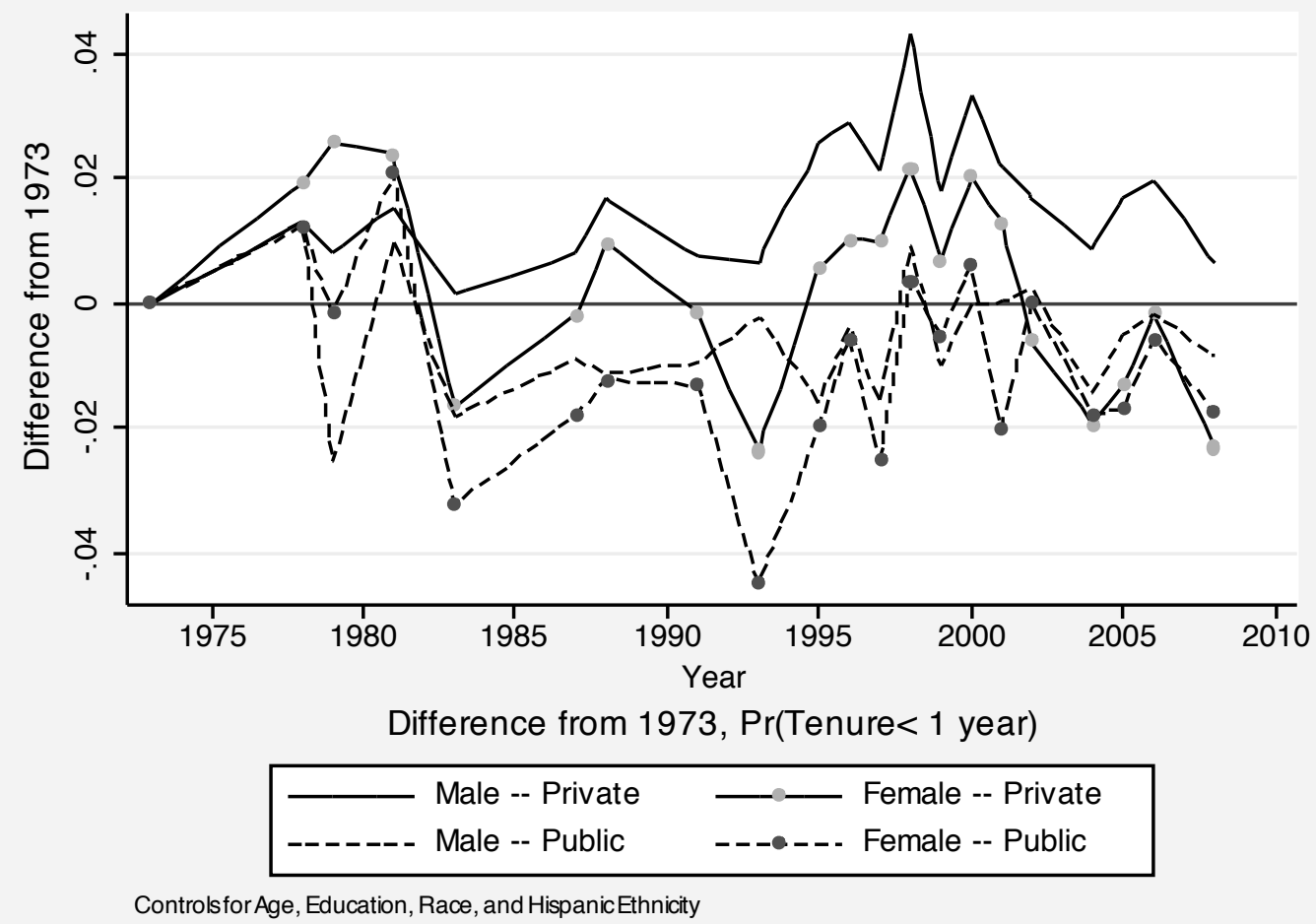

Figure 10: Year Effects on $\operatorname{Pr}(T<1)$

interesting questions regarding the decline in mean tenure and long term employment and how this decline is related to the rate of "churning" in the labor market:

1. Are young workers taking longer to find good (long-lasting) matches or jobs? This would imply an increase in the new-job rate among younger workers.

2. Are older workers having more difficulty finding good matches when they lose jobs that may formerly have been "lifetime" jobs? This would imply an increase in the new-job rate among older workers.

An implicit constraint in the model I use to estimate the changes (based on equation 3.3) presented in figure 10 is that the changes over time are are constant across age groups. Given the role that job change plays in matching and job search early in careers, I estimate separate year effects for different age groups. The top panel of figure 11 contains differences by year in the new-job rate relative to the 1973 estimated using a sample of workers aged 20-29. These estimates, which vary quite a bit year-to-year, show no secular pattern but a strong cyclical pattern. The regression-adjusted private-sector new-job rate for both sexes is higher in stronger economic times as employers increase hiring and lower in weaker times 


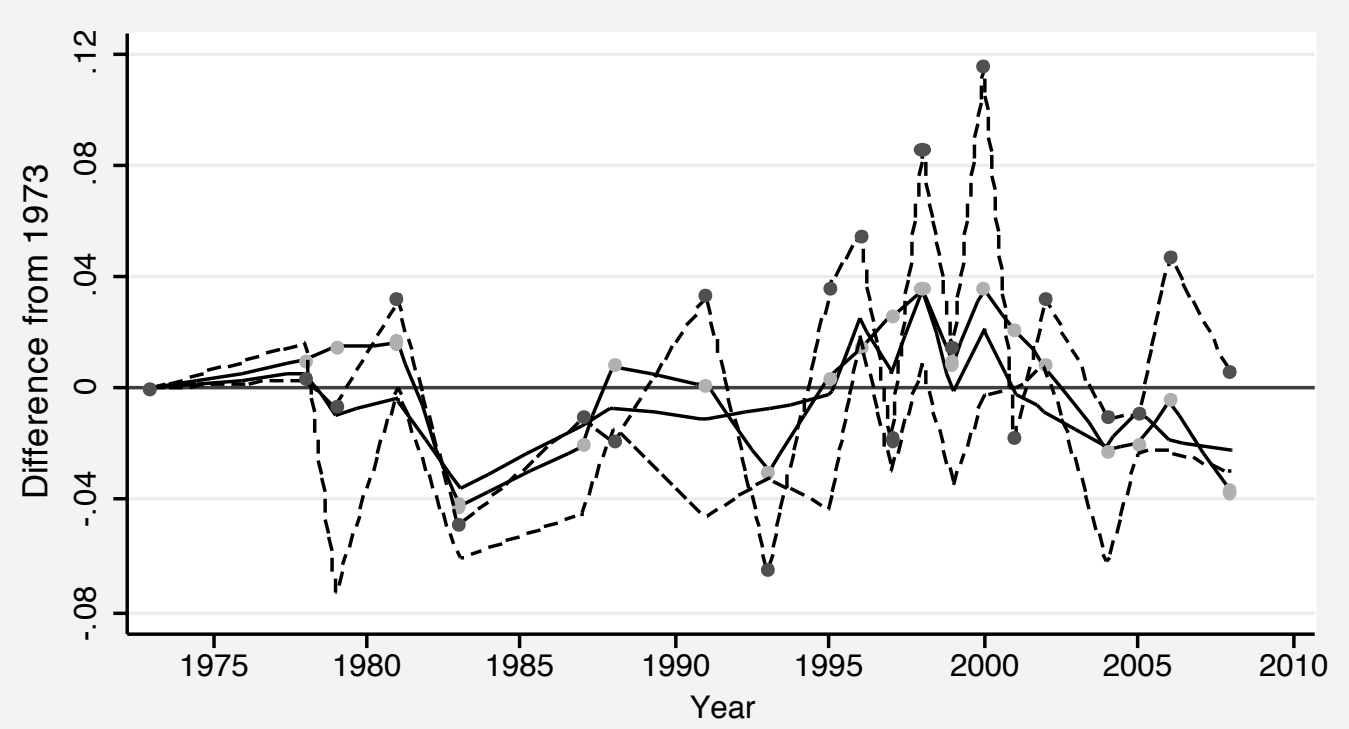

Difference from 1973, $\operatorname{Pr}(T e n u r e<1$ year) -- Age 20-29

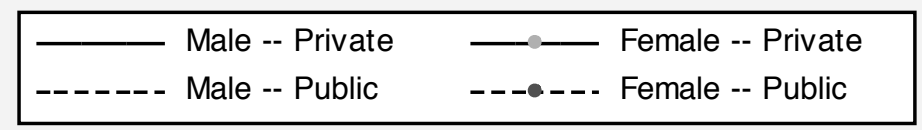

Controlsfor Age, Education, Race, and Hispanic Ethnicity

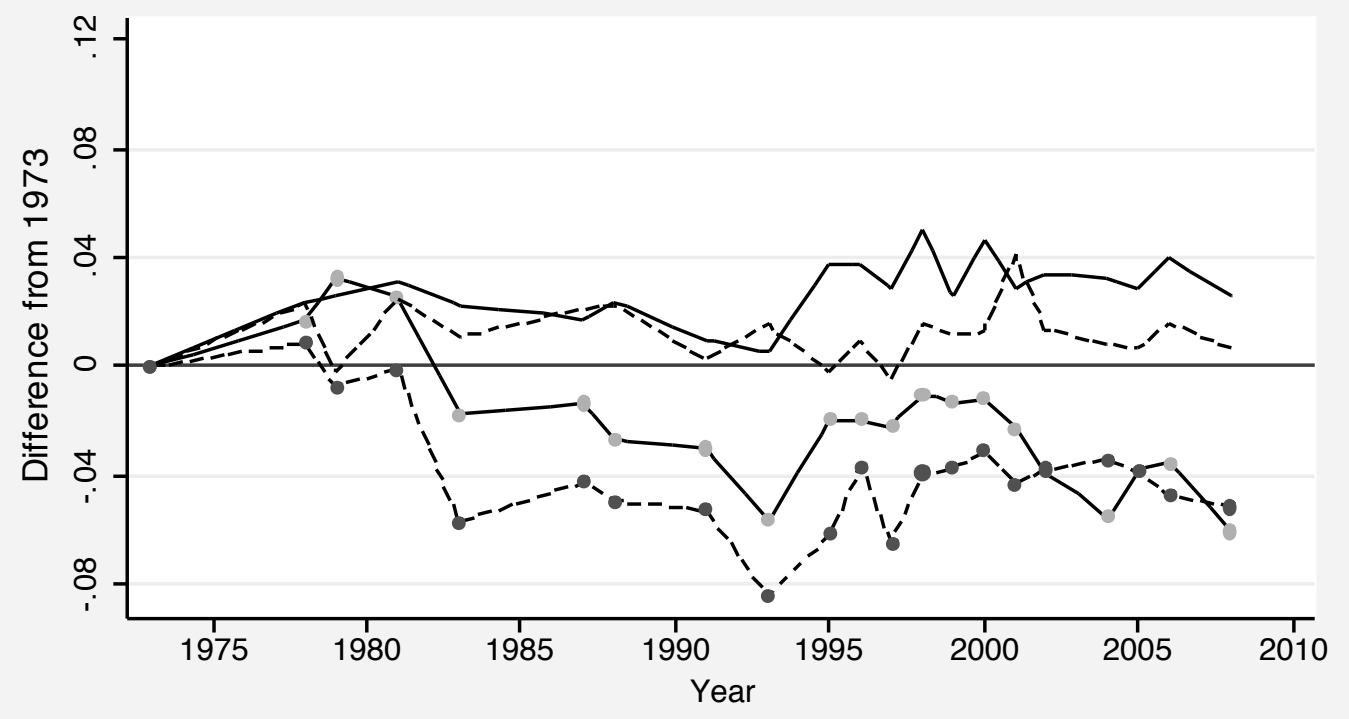

Difference from 1973, $\operatorname{Pr}($ Tenure $<1$ year) -- Age 30-39

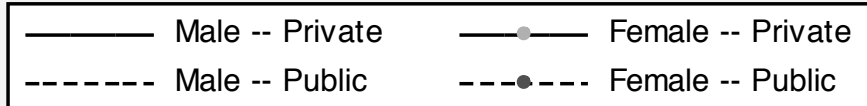

Controlsfor Age, Education, Race, and Hispanic Ethnicity

Figure 11: Year Effects on $\operatorname{Pr}(T<1)$ (Age 20-29 and 30-39) 
as workers are less likely to quit to take new jobs. The public sector adjusted new job rate fluctuates dramatically over time.

The bottom panel of figure 11 contains differences by year in the new-job rate relative to 1973 estimated using a sample of workers aged 30-39. These estimated year effects differ substantially from those for workers in their twenties. There is an increase of about 4 percent in the new job rate for males in their thirties in the private sector and a decrease of about 4 percent for females in their thirties in both sectors between the 1973 and 2008. The pattern for males is consistent with the hypothesis that men are job shopping in their twenties and have become less likely to settle into longer-term jobs in their thirties. The pattern for females, which is stronger in the public sector, likely reflects an increase in attachment to the labor force by women as they enter their thirties.

Given that older workers are less likely to be in new jobs, I next investigate how the new-job rate has changed for workers aged 40 and older. The top panel of figure 12 contains differences by year in the new-job rate relative to 1973 estimated using a sample of workers aged 40-49. The bottom panel of this figure contains differences by year in the new-job rate relative to 1973 using a sample of workers aged 50-64. Both plots show an increase in the probability of being on a new job for males employed in the private sector, although this effect is diminished in 2008 among men 50-64. The magnitude of the increase (about 2 percentage points) is substantial when compared to the overall mean new job rates for older men in table 2. The new-job rate for women in their forties in the public sector decreased substantially, but the change is not reflected in the experience of women 50 and older.

The overall time-series pattern of the age-specific new-job rate is a general increase over time for men aged 30 and older. Part of this reflects an extension of the period of "jobshopping" early in careers and part reflects increased probabilities of jobs ending later in careers. There is not much change over time in the age-specific new-job rate for women in either the public or private sectors aside from a substantial decline for women in their thirties, likely reflecting a reduced likelihood of withdrawing from and subsequently re-entering the labor force.

\section{The Rate of Job Loss}

The decline in job tenure in the private sector documented here could be the result of increased rates of increased job loss and/or increased voluntary job change. While there is not a large-scale comprehensive series on voluntary mobility, the Displaced Workers Survey (DWS) does measure job loss. The DWS, administered every two years since 1984 as a supplement to the Current Population Survey (CPS), is perhaps the most comprehensive source of information on the incidence and costs of job loss in the United States. In this section, I analyze data on 985,508 individuals between the ages of twenty and sixty-four from 


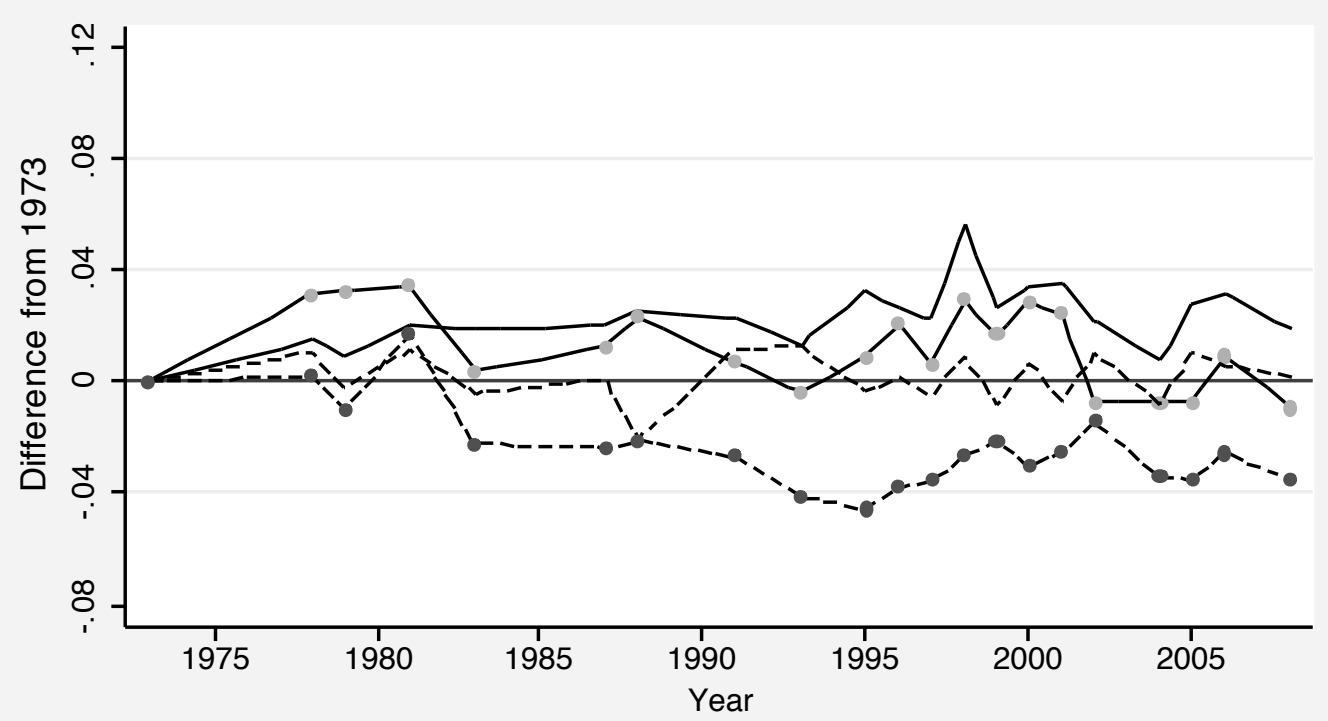

Difference from 1973, $\operatorname{Pr}($ Tenure $<1$ year) -- Age 40-49

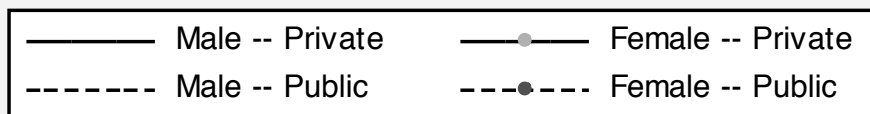

Controlsfor Age, Education, Race, and Hispanic Ethnicity

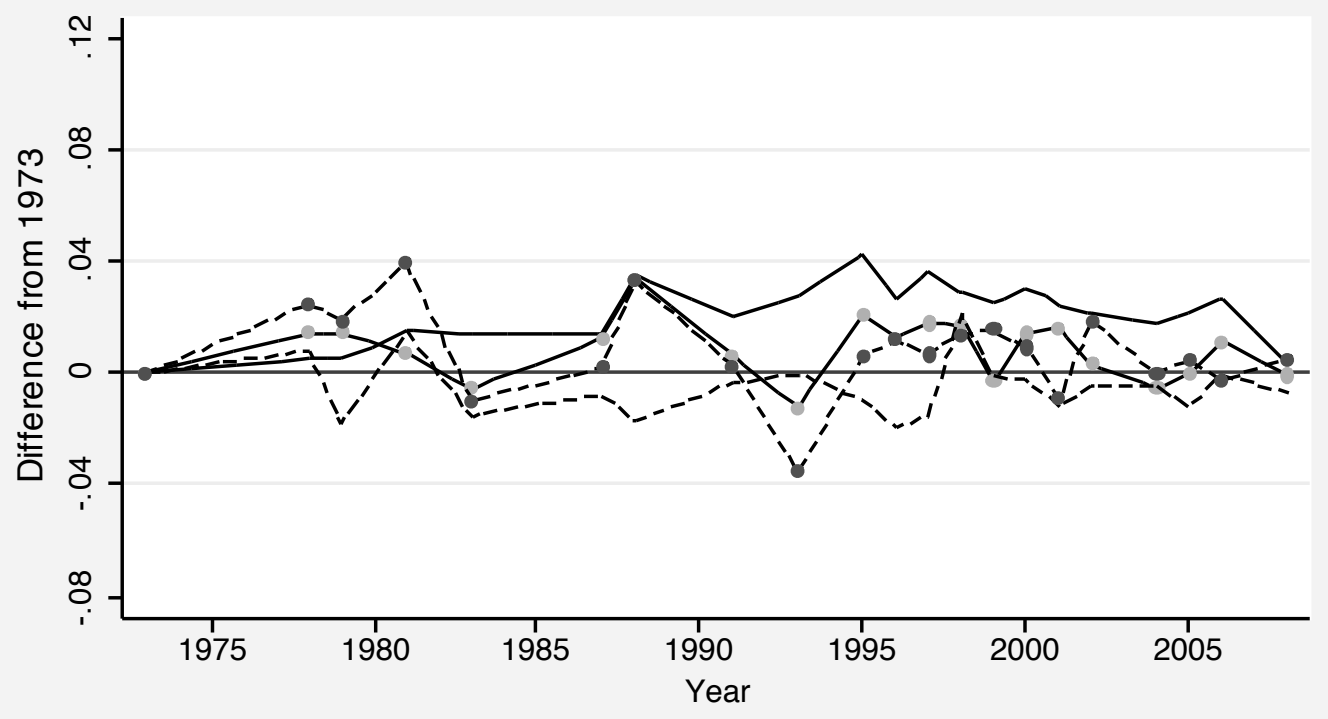

Difference from 1973, $\operatorname{Pr}($ Tenure $<1$ year) -- Age 50-64

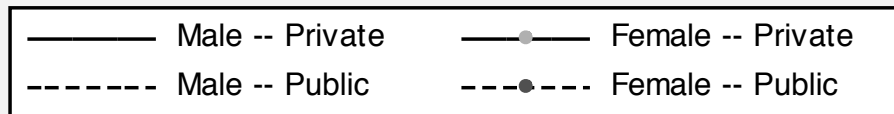

Controlsfor Age, Education, Race, and Hispanic Ethnicity

Figure 12: Year Effects on $\operatorname{Pr}(T<1)$ (Age 40-49 and 50-64) 
the DWSs conducted as part of the January CPSs in 1984, 1986, 1988, 1990, 1992, 2002, 2004, 2006, and 2008 and the February CPSs in 1994, 1996, 1998, and 2000.

There are three important issues of measurement and interpretation that arise when comparing job loss rates calculated using the DWS over time.

1. The DWS asks only about a single involuntary job loss. The survey does not capture multiple job losses by the same worker. Neither does it capture worker terminations "for cause." The survey is meant to capture worker terminations as the result of business decisions of the employer unrelated to the performance of the particular employee (e.g., a plant closing, a layoff, the abolition of a job). Thus, the measure of the job loss rate that I calculate is the fraction of workers who lost at least one job not "for cause" in the relevant period rather than the rate of destruction of worker-employer matches.

2. The DWS from 1984-1992 asked about job separations in the previous five years while the later DWS asked about job separation in the previous three years. The measure of job loss that I use is adjusted to account for this change in the recall period so that all rates are reported on a three-year basis. This adjustment is detailed in Farber (1997).

3. The basic wording of key questions changed since the inception of the DWS in 1984 . This may have affected whether survey respondents would report a job separation in a particular circumstance as an involuntary separation in one survey but would not report a separation in the same circumstance as involuntary in another year. In Farber (1998) and Farber (2004), I use additional data from debriefing questions asked of a fraction of DWS respondents in 1996, 1998, and 2000 to investigate how changes in the wording of the key question may have affected the likelihood that a worker reported a particular separation as an involuntary job change. I use the results of that analysis to calculate re-weighted job loss rates that I present in this study. ${ }^{14}$

In these surveys, I count as job losers workers who reported a job loss in the three calendar years prior to the survey. Based on these data, I calculate the rate of job loss as the ratio of the number of reported job losers divided by the number of workers who were either employed at the survey date or reported a job loss but were not employed at the survey date. I then adjust these job loss rates as described in Farber (2004) to account for the change in the recall period from five years to three years in 1994 and changes in the wording of the key job loss question.

Figure 13 contains plots of adjusted three-year job loss rates for the private and public sectors computed from each of the thirteen DWSs from 1984-2008 along with the average

\footnotetext{
14 Job losers are asked to report the reason for their job loss. One allowable response is "other." The adjustment for changes in the wording of the key job loss question discounts job loss rates for "other" reasons by $37.4 \%$ for the 1984-1992 DWS and by $74.8 \%$ for the 1994 and later DWSs. See Farber (1998) for details.
} 


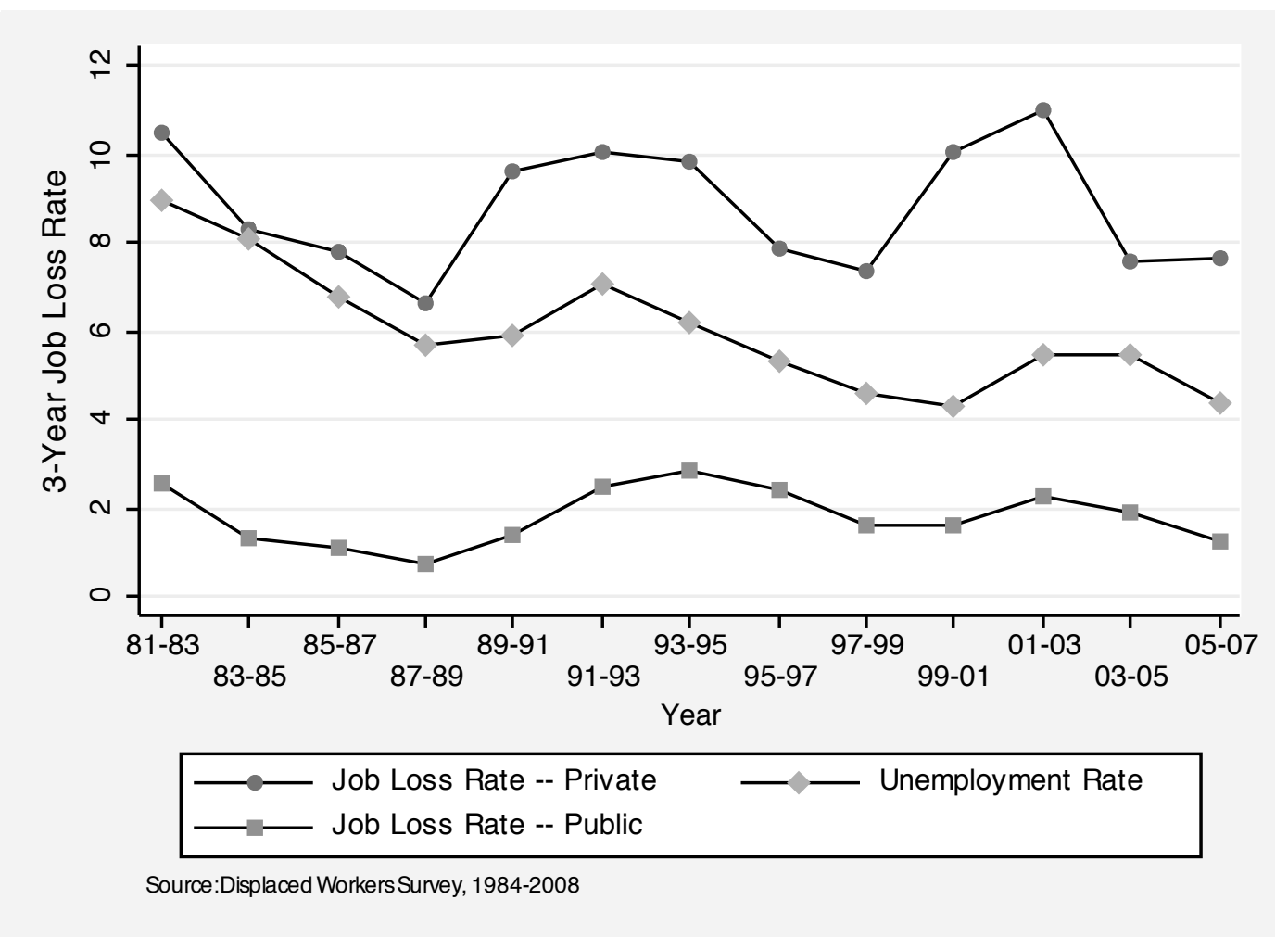

Figure 13: Unemployment and Job Loss Rates, by Year

civilian unemployment rate for each three-year period. ${ }^{15}$ Two facts are clear from this figure.

1. Job loss is cyclical, with job-loss rates clearly positively correlated with the unemployment rate. Both unemployment and job-loss rates were relatively high in the 1981-83 period, and they both fell sharply during the expansion of the mid-1980's. However, the private-sector job-loss rate rose much more sharply from the 1987-89 to the 1989-91 period than did the unemployment rate. The job-loss rate rose by fully 3.1 percentage points (from 6.7 percent to 9.6 percent) while the average unemployment rate rose by only 0.2 percent (from 5.7 percent to 5.9 percent) over this period. Between 1993 and 1999, both the private-sector job-loss and unemployment rates fell sharply, but the gap between them remained larger than in the strong labor market of the late 1980s. The unemployment rate continued to fall in the 1999-2001 period before rising somewhat in the 2001-03 period. The private-sector job loss rate rose sharply after the 1997-99 trough through the 2001-03 period before falling off in the 2003-05 period. ${ }^{16}$

${ }^{15}$ Information on rates of job loss is presented most accessibly in graphical form, and the discussion here is organized around a series of figures. All counts are weighted using the CPS sampling weights.

16 The use of three-year averages here hides the facts that the job loss rate was steady in 1999 and 2000 
2. The rate of job loss in the public sector is approximately one-fourth of the privatesector rate, and it exhibits less cyclical sensitivity. To the extent that private-sector jobs have become less secure, it may be the case that public sector jobs have become relatively more attractive. The resulting lower quit rates from public sector jobs would serve to reinforce the already high level of job security evident in the public sector.

Figure 14 contains three-year rates of job loss by year for each of four education categories separately for the private and public sectors. The top panel of the figure presents the job loss rates for the private sector. Private-sector job loss rates were dramatically higher for less educated workers in the 1980s, but there has been steady convergence in rates of job loss since that time. In 1981-83, the private-sector three-year job-loss rate was 16 percent for high-school graduates and 9.4 percent for college graduates. By 2001-03 (also a period of weak labor markets), the gap had fallen to virtually zero, with a private-sector three-year job-loss rate of 10.7 percent for high-school graduates and 11 percent for college graduates. Interestingly, the education gap in job-loss rates increased in the 2005-07 period with 8.3 and 10.0 percent job-loss rates for high-school and college graduates respectively. There is a clear cyclical pattern in job loss rates for all groups of workers in the private sector, and it appears that rates of job loss for less educated have declined in the private sector.

The lower panel of figure 14 presents the job loss rates for the public sector. As expected, they are much lower than in the private sector. Interestingly, there is only a small difference between job-loss rates by education level, even in the earlier years. And, aside from a mild cyclical pattern and some increase in rate of job loss for the least educated workers, there is no change in rates of job loss in the public sector.

Figure 15 contains three-year job-loss rates by year for four age groups covering the range from 20-64 years. In the private sector (top panel), rates of job loss generally show the standard cyclical pattern for each age group. Early in the period, job-loss rates are highest for the youngest workers (20-39 years of age) but these differences by age disappear in the late 1980s. The general pattern is similar in the public sector with generally lower levels of job loss and an attenuated cyclical pattern. It does appear the the job-loss rates of the youngest workers (aged 20-29) remains above that of older workers. There is no evidence of a secular increase in job loss rates among older workers in either the private or public sectors. In fact, job-loss rates have declined, particularly for younger workers.

before increasing sharply in 2001 while the unemployment rate declined slightly in 1999 and 2000 before increasing slightly in 2001. 


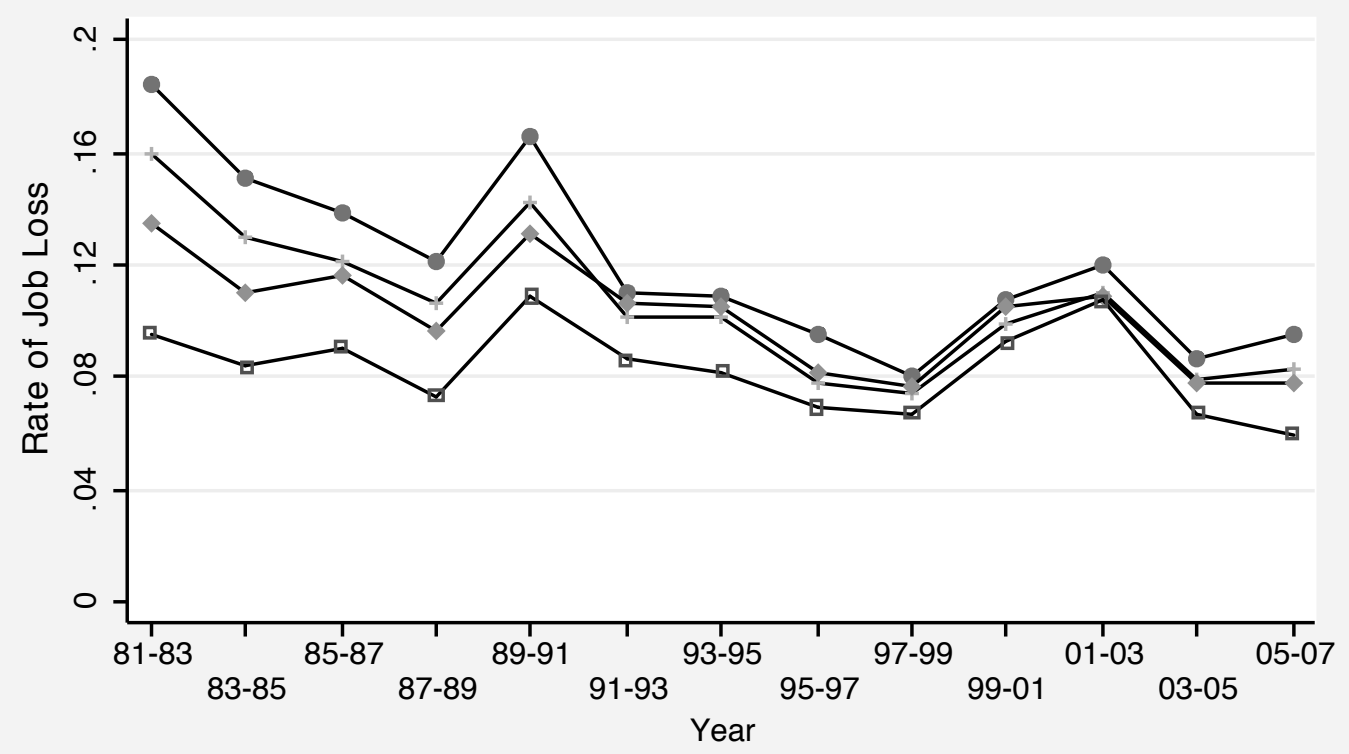

3-yr Job Loss Rate -- Private Sector
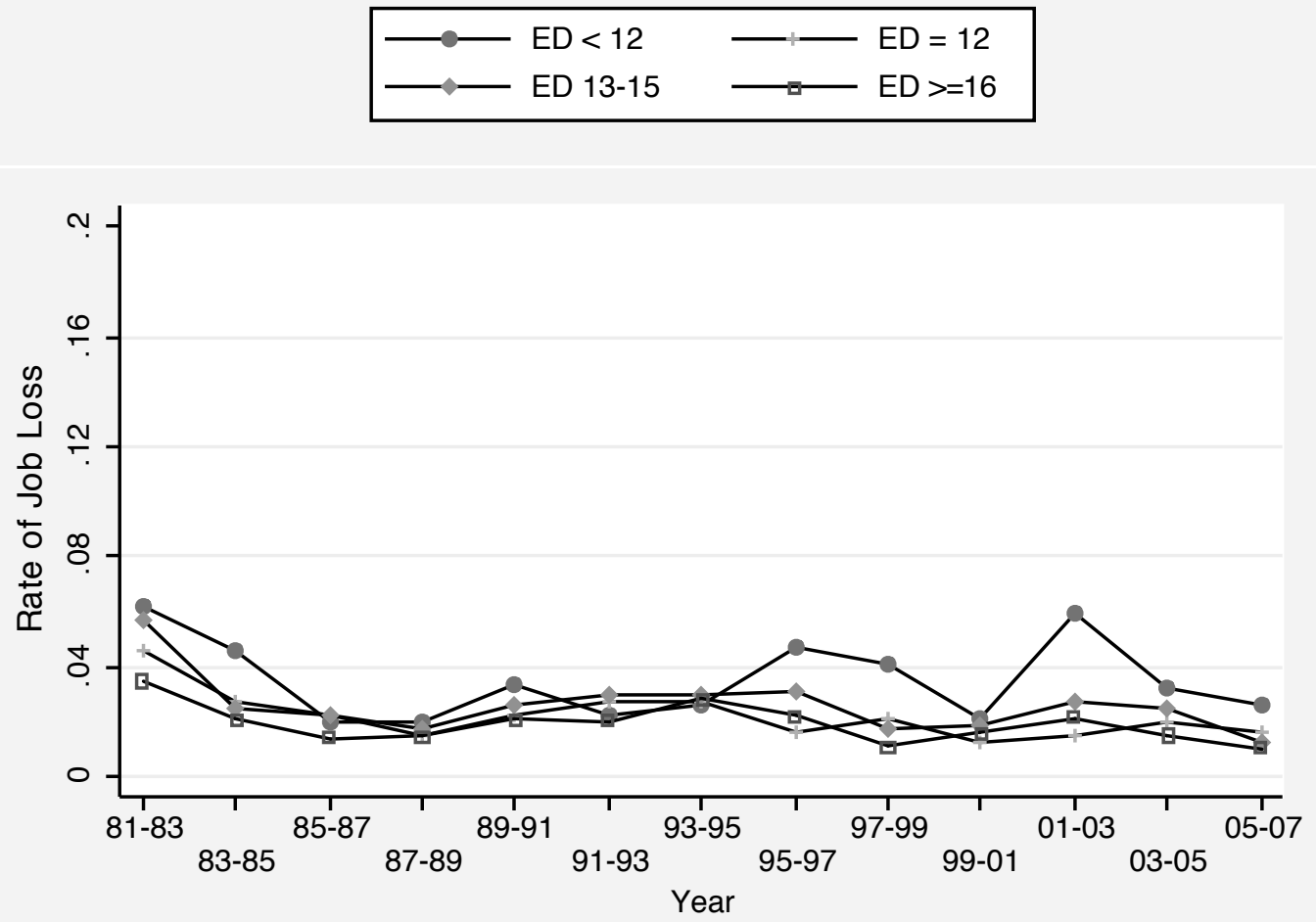

3-yr Job Loss Rate -- Public Sector

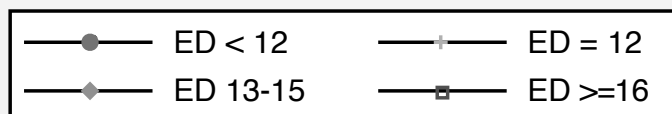

Figure 14: Three-Year Job Loss Rate by Education, 1981-2007. 

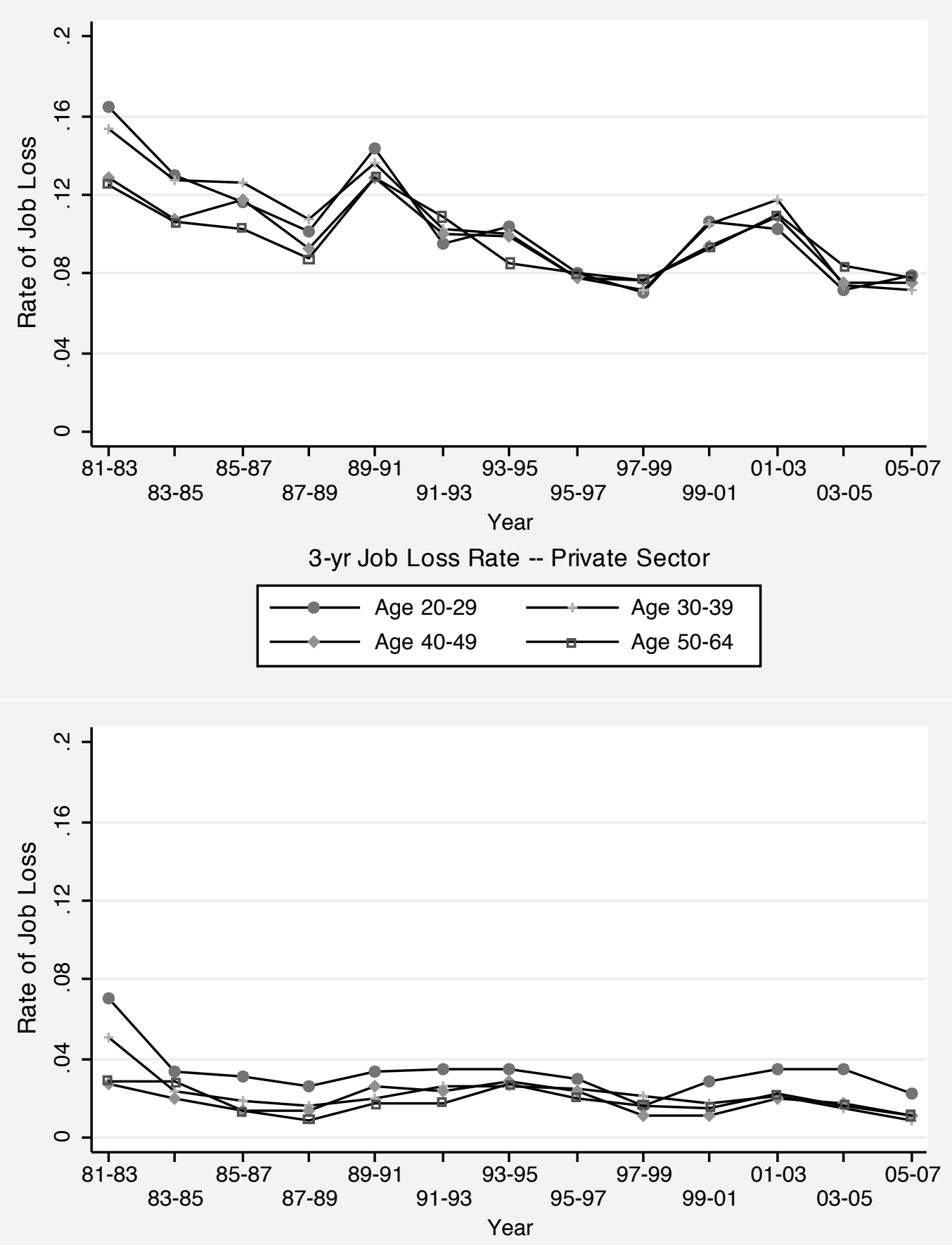

3-yr Job Loss Rate -- Public Sector

$\longrightarrow$ Age $20-29 \quad$ Age $30-39$
$\longrightarrow$ Age $50-64$

Figure 15: Three-Year Job Loss Rate by Age, 1981-2007. 


\section{Reconciling the Trends in Job Tenure and Job Loss}

The sharp decline in job tenure in the private sector combined with the lack of any trend in rates of job loss presents a puzzle. In this section, I explore the possibility that this apparent contradiction is due to a relative increase in job-loss rates among high-tenure workers.

Unfortunately, the available data do not allow direct calculation job-loss rates by tenure. Tenure is not observed in the DWS for workers who do not report that they have been displaced. I use Bayes' rule to recover the probability of job loss by tenure category using the tenure data from the CPS as well as the DWS. The appropriate relationship defining the probability that worker $i$ in tenure category $j$ is displaced in period $t$ is

$$
\operatorname{Pr}\left(D_{i t}=1 \mid T_{i t}=j\right)=\frac{\left.\operatorname{Pr}\left(T_{i t}=j \mid D_{i t}=1\right)\right) \operatorname{Pr}\left(D_{i t}=1\right)}{\operatorname{Pr}\left(T_{i t}=j\right)}
$$

where $D_{i t}=1$ if worker $i$ in period $t$ suffers a job loss and $T_{i t}=j$ if worker $i$ is in tenure category $j$ in period $t$. The only piece of equation 5.1 that is not available directly from the DWS is $\operatorname{Pr}\left(T_{i t}=j\right)$, the unconditional tenure distribution. However, data from the CPS on job tenure are available for all workers in at least one of the two years immediately prior to each DWS other than the 1986 DWS. I use this information to compute unconditional tenure distributions appropriate to each DWS (other than 1986). ${ }^{17}$

Tenure-specific job-loss rates calculated based on equation 5.1 are plotted in figure 16 separately for the private and public sectors. The top panel, for the private sector, shows the unsurprising result that the probability of job loss is strongly monotonically declining in tenure. The likelihood of job loss (averaged across years) falls from 14.7 percent for workers in their first year on the job to 5.6 percent for workers with more than twenty years on the job. The results are more remarkable for what is not found. There seems to be no secular trend in the tenure-specific probabilities of job loss in the private sector. The plots in the bottom panel of figure 16 show the typically much lower rates of job loss in the public sector, with a smaller (in absolute value) decline in the rate of job loss with tenure. Again, there is not secular trend in rates of job in the public sector.

Covariation between sex, age, education, and tenure in determining the rate of job loss suggests that a multivariate analysis of job loss would be useful. Without longitudinal data on all variables, a micro-level analysis is not feasible, but I can compute cell-mean level rates of job loss using the Bayes' Rule approach. I compute job-loss rates for groups defined by sector of employment, education category, tenure category, age category, sex, and time

\footnotetext{
17 Since 1994, the DWS collects information on tenure on the lost job only for the subset of displaced workers who report a reason for job loss of 1) slack work, 2) position or shift abolished, or 3) plant closing. This information is not collected for displaced workers who report a reason for job loss of 1) temporary job ended, 2) seasonal job ended, or 3) other. For this reason, the succeeding analysis measures rates of job loss only for the "big three" reasons. See Farber (2005) for more details.
} 


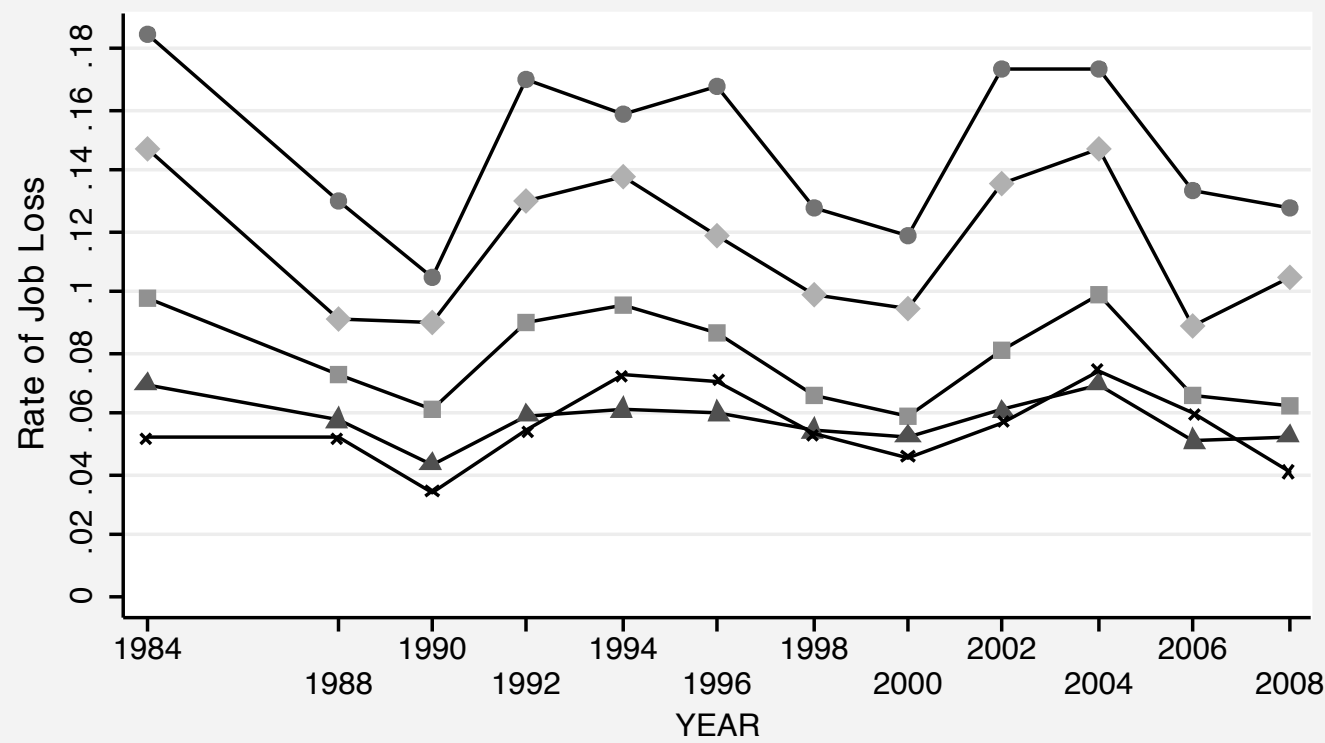

3-yr Job Loss Rate - Private Sector
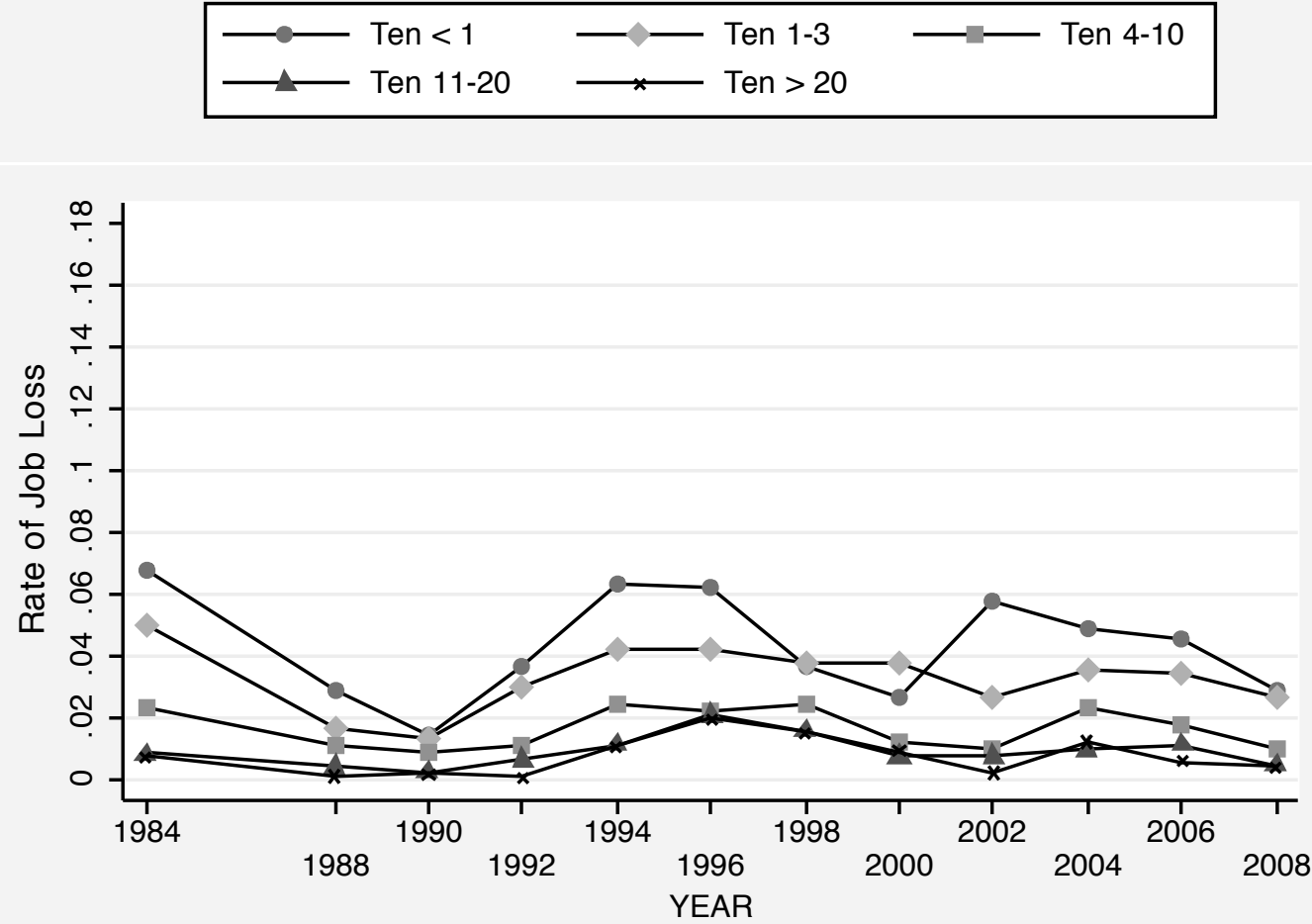

3-yr Job Loss Rate - Public Sector

$\longrightarrow$ Ten $<1$
Ten $11-20$
$\longrightarrow$ Ten $>20$$\quad$ Ten $1-3 \quad \longrightarrow$ Ten $4-10$

Figure 16: Three-Year Job Loss Rate by Tenure, 1984-2008. 
period. There are 4224 cells, defined by these five variables, for which I have computed job loss rates using information on individual characteristics and job displacement from the CPS mobility data and the DWS. Unfortunately, cell sizes are too small to expand the breakdown to include other variables.

The job loss rates for each category are computed using Bayes' rule applied to the conditional probabilities associated with job loss, tenure, sex, and education. It is straightforward to show that, within each sector,

$$
\operatorname{Pr}\left(D_{i t}=1 \mid T_{i t}=j, X_{i k r m t}=1\right)=\frac{\operatorname{Pr}\left(T_{i t}=j \mid D_{i t}=1, X_{i k r m t}=1\right) \operatorname{Pr}\left(D_{i t}=1, X_{i k r m t}=1\right)}{\operatorname{Pr}\left(T_{i t}=j, X_{i k r m t}=1\right)}
$$

where $X_{i k r m t}=1$ if individual $i$ in year $t$ is of sex $k$ in age category $r$ with education level $m$. This particular representation of the conditional probability of job loss is used because it allows computation of the probability of displacement conditional on tenure and the other controls without direct information on the joint distribution of displacement and tenure.

Table 3 contains estimates of weighted least squares (WLS) regressions of the log of the probability of job loss in a cell on the characteristics defining the cell. The weights used for each cell are estimates of the variance of the log probability of job loss for that cell. ${ }^{18}$

Specification 1 in table 3 contains estimates of a model pooling all years of the log probability of job loss with main effects for sex, age category, education level, tenure category, sector of employment, and DWS survey year. ${ }^{19}$ These results demonstrate several strong patterns:

- There is a strong negative relationship between the probability of job loss and tenure. Workers with more than twenty years of tenure have a probability of job loss that is 35 percent of the rate of job loss of workers in their first year on the job.

- Females have lower rates of job loss than men (about 22 percent lower).

18 The log of the probability of job loss in equation 5.2 is a linear combination of the logs of its component probabilities. Specifically,

$$
\begin{aligned}
\ln \left(\operatorname{Pr}\left(D_{i t}=1 \mid T_{i t}=j, X_{i k r m t}=1\right)\right) & =\ln \left(\operatorname{Pr}\left(T_{i t}=j \mid D_{i t}=1, X_{i k r m t}=1\right)\right) \\
& +\ln \left(\operatorname{Pr}\left(D_{i t}=1, X_{i k r m t}=1\right)\right)-\ln \left(\operatorname{Pr}\left(T_{i t}=j, X_{i k r m t}=1\right)\right) .
\end{aligned}
$$

The variance of each component probability is $p(1-p) / n$, where $p$ is the relevant probability and $n$ is the sample size that the estimate of the probability is based on. The variance of the log of each probability is computed using the delta method as $(1-p) / p n$, and the variance of $\ln \left(\operatorname{Pr}\left(D_{i t}=1 \mid T_{i t}=j, X_{i k r m t}=1\right)\right)$ is computed as the sum of the variances of the log of the three component probabilities.

19 The log specification of the rate of job loss neatly allows the pooling of the public and private sector job loss rates despite the large disparity in the levels of these job loss rates. The log specification implies a constant proportional effect of the included variables on the job loss rate, and this reflects the lower level and smaller absolute variation in the public-sector job-loss rates. 
Table 3: WLS Estimates of Log-Probability of Job Loss, 1984-2008 by Sex, Education, Tenure, Age, Sector and Year Cells

\begin{tabular}{|c|c|c|c|c|}
\hline Variable & $\begin{array}{c}(1) \\
1984-08\end{array}$ & $\begin{array}{c}(2) \\
1984-90\end{array}$ & $\begin{array}{c}(3) \\
1992-00\end{array}$ & $\begin{array}{c}(4) \\
2002-08\end{array}$ \\
\hline \multirow[t]{2}{*}{ Ten 1-3 } & -0.204 & -0.203 & -0.203 & -0.207 \\
\hline & $(0.019)$ & $(0.035)$ & $(0.029)$ & $(0.033)$ \\
\hline \multirow[t]{2}{*}{ Ten 4-10 } & -0.664 & -0.632 & -0.646 & -0.714 \\
\hline & $(0.019)$ & $(0.035)$ & $(0.029)$ & $(0.033)$ \\
\hline \multirow[t]{2}{*}{ Ten 4-10 } & -1.008 & -0.986 & -1.005 & -1.035 \\
\hline & $(0.026)$ & $(0.049)$ & $(0.039)$ & $(0.045)$ \\
\hline \multirow[t]{2}{*}{ Ten 11-20 } & -1.068 & -1.096 & -1.032 & -1.095 \\
\hline & $(0.034)$ & $(0.068)$ & $(0.052)$ & $(0.058)$ \\
\hline \multirow[t]{2}{*}{ Female } & -0.245 & -0.334 & -0.233 & -0.192 \\
\hline & $(0.014)$ & $(0.026)$ & $(0.021)$ & $(0.024)$ \\
\hline \multirow[t]{2}{*}{$\mathrm{ED}<12$} & 0.321 & 0.220 & 0.328 & 0.452 \\
\hline & $(0.024)$ & $(0.038)$ & $(0.039)$ & $(0.051)$ \\
\hline \multirow[t]{2}{*}{ ED 13-15 } & -0.037 & -0.110 & -0.002 & -0.001 \\
\hline & $(0.017)$ & $(0.033)$ & $(0.026)$ & $(0.030)$ \\
\hline \multirow[t]{2}{*}{$\mathrm{ED} \geq 16$} & -0.257 & -0.456 & -0.211 & -0.173 \\
\hline & $(0.018)$ & $(0.036)$ & $(0.028)$ & $(0.031)$ \\
\hline \multirow[t]{2}{*}{ Age 25-34 } & 0.204 & 0.183 & 0.176 & 0.274 \\
\hline & $(0.026)$ & $(0.043)$ & $(0.041)$ & $(0.050)$ \\
\hline \multirow[t]{2}{*}{ Age 35-44 } & 0.255 & 0.200 & 0.283 & 0.300 \\
\hline & $(0.027)$ & $(0.046)$ & $(0.042)$ & $(0.050)$ \\
\hline \multirow[t]{2}{*}{ Age 45-54 } & 0.326 & 0.175 & 0.352 & 0.425 \\
\hline & $(0.028)$ & $(0.052)$ & $(0.044)$ & $(0.050)$ \\
\hline \multirow[t]{2}{*}{ Age 55-64 } & 0.470 & 0.350 & 0.509 & 0.553 \\
\hline & $(0.031)$ & $(0.057)$ & $(0.050)$ & $(0.055)$ \\
\hline \multirow[t]{2}{*}{ Public Sector } & -0.721 & -0.836 & -0.668 & -0.679 \\
\hline & $(0.022)$ & $(0.041)$ & $(0.034)$ & $(0.039)$ \\
\hline Year FEs & Yes & Yes & Yes & Yes \\
\hline $\mathrm{N}$ & 3916 & 986 & 1628 & 1302 \\
\hline R-squared & 0.580 & 0.669 & 0.550 & 0.569 \\
\hline
\end{tabular}

Note: Based on calculated conditional cell probabilities from equation 5.2 using data from the 1984-2008 DWS and tenure data from various CPSs from 1983-2008. The estimates are weighted by the inverse sampling variance of the log probability of job loss in each cell. See Note 18 for details. 
- Rates of job loss are inversely related to education. The rate of job loss for college graduates is 77 percent of the rate of job loss of otherwise-equivalent high school graduates (the base group).

- Controlling for tenure, there is a positive relationship between age and the rate of job loss. Workers ages 55-64 have a rate of job loss that is about 30 percent higher than workers aged 25-34.

- Job loss rates are substantially (51 percent) lower in the public sector than in the private sector.

Of course, the key question is whether these relationships have changed over time. In order to investigate this, I re-estimated the model separately for three sub-periods: 19841990, 1992-2000, and 2000-2008. ${ }^{20}$ These results are interesting both for the changes revealed in some dimensions and the lack of change in others.

- Conditional on age, there is no systematic change over time in the relationship of the displacement rate with job tenure. This suggests that we cannot reconcile the decline in age-specific job tenure in the U.S. and the lack of increase in rates of job loss with changes in the tenure distribution of job loss.

- The female-male differential in job loss has narrowed, falling from 28 percent lower for females in the 1980s to 17 percent lower in the 2000s.

- The strong advantage of education in reducing job-loss rates has diminished substantially. The college/high-school differential in job loss rates fell from 37 percent lower in the 1980s to 16 percent lower in the 2000s.

- Conditional on tenure, older workers have become substantially more susceptible to job loss. Workers aged 45-54 had job-loss rates 19 percent higher than workers aged 20-24 in the 1980s. By the 2000s, these workers job-loss rates were 53 percent higher than those of workers 20-24.

- The private public sector gap in job-loss rates fell somewhat over time. The public sector job-loss rate was 57 percent lower than the private sector rate in the 1980s. This gap fell to 49 percent in the 2000s.

The strong positive relationship between age and tenure may be masking a change in relationship between the probability of job loss and tenure. To this end, I re-estimate the

\footnotetext{
20 These years refer to the DWS survey years. The 1984-1990 sample covers job loss from 1981-1989, the 1992-2000 sample covers job loss from 1989-1999, and the 2000-2008 sample covers job loss from 1999-2007.
} 
Table 4: WLS Estimates of Log-Probability of Job Loss by Sex, Education, Tenure, and Year Cells, 1984-2008

\begin{tabular}{|c|c|c|c|c|}
\hline Variable & $\begin{array}{c}(1) \\
1984-08\end{array}$ & $\begin{array}{c}(2) \\
1984-90\end{array}$ & $\begin{array}{c}(3) \\
1992-00\end{array}$ & $\begin{array}{c}(4) \\
2002-08\end{array}$ \\
\hline \multirow[t]{2}{*}{ Ten 1-3 } & -0.228 & -0.224 & -0.224 & -0.235 \\
\hline & $(0.020)$ & $(0.036)$ & $(0.030)$ & $(0.034)$ \\
\hline \multirow[t]{2}{*}{ Ten 3-10 } & -0.629 & -0.607 & -0.608 & -0.678 \\
\hline & $(0.020)$ & $(0.037)$ & $(0.030)$ & $(0.034)$ \\
\hline \multirow[t]{2}{*}{ Ten 11-20 } & -0.952 & -0.967 & -0.945 & -0.969 \\
\hline & $(0.028)$ & $(0.052)$ & $(0.042)$ & $(0.049)$ \\
\hline \multirow[t]{2}{*}{ Ten $>20$} & -0.979 & -1.186 & -0.904 & -0.955 \\
\hline & $(0.038)$ & $(0.077)$ & $(0.057)$ & $(0.064)$ \\
\hline \multirow[t]{2}{*}{$\mathrm{ED}<12$} & 0.202 & 0.199 & 0.193 & 0.171 \\
\hline & $(0.026)$ & $(0.040)$ & $(0.041)$ & $(0.055)$ \\
\hline \multirow[t]{2}{*}{ ED 13-15 } & -0.075 & -0.167 & -0.041 & -0.038 \\
\hline & $(0.019)$ & $(0.036)$ & $(0.028)$ & $(0.032)$ \\
\hline \multirow[t]{2}{*}{$\mathrm{ED} \geq 16$} & -0.272 & -0.517 & -0.229 & -0.176 \\
\hline & $(0.020)$ & $(0.040)$ & $(0.030)$ & $(0.033)$ \\
\hline \multirow[t]{2}{*}{ Female } & -0.246 & -0.349 & -0.231 & -0.191 \\
\hline & $(0.015)$ & $(0.028)$ & $(0.023)$ & $(0.026)$ \\
\hline \multirow[t]{2}{*}{ Public Sector } & -1.132 & -1.223 & -1.060 & -1.146 \\
\hline & $(0.031)$ & $(0.059)$ & $(0.045)$ & $(0.055)$ \\
\hline Age & No & No & No & No \\
\hline Year FEs & Yes & Yes & Yes & Yes \\
\hline $\mathrm{N}$ & 955 & 240 & 400 & 315 \\
\hline R-squared & 0.836 & 0.888 & 0.832 & 0.826 \\
\hline
\end{tabular}

Note: Based on calculated conditional cell probabilities from equation 5.2 using data from the 1984-2008 DWS and tenure data from various CPSs from 1983-2008. The estimates are weighted by the inverse sampling variance of the log probability of job loss in each cell. See Note 18 for details.

model presented in table 3 without controlling for age. ${ }^{21}$ The results of this analysis are presented in table 4, and they are quite similar to those controlling for age. There is no evidence that the strong negative relationship between tenure and rates of job loss has weakened.

Thus, the puzzle of declining job tenure over time with no increase in measured rates of job loss in the DWS remains. One real possibility is that the DWS does not measure rates of job loss very well, perhaps because of ambiguity among workers who leave jobs in why they,

${ }^{21}$ In other words, I estimate the model over cells that do not condition on age. 
in fact, left. For example, workers who accept buy-outs to leave their jobs may perceive this as a voluntary job change and not report this as a job loss. To the extent that this is an important phenomenon, rates of job change, whether classified as voluntary or involuntary, have increased.

\section{Final Remarks}

The analysis shows clearly that job tenure and the incidence of long-term employment have declined sharply in the U.S. private sector between the 1970s and 2008. In contrast, the job tenure and the incidence of long-term employment have increased in public sector over the same period.

My examination of rates of job loss, as measured by the Displaced Workers Survey (DWS), showed that, while job-loss rates are lower in the public sector than in the private sector and move with the business cycle in the private sector, there has been no secular increase in private-sector job loss rates that could account for the decline in private-sector job tenure. I ruled out one potential solution to this apparent inconsistency. While overall rates of job loss did not increase, it is not the case that rates of job loss for high-tenure workers increased relative to those for lower-tenure workers.

A more likely explanation is that there has been an increase in rates of job change that is not captured in the limited questions on job change asked in the DWS. Some of this seemingly voluntary job change (e.g., the taking of an oered buy-out) may reect the kind of worker displacement that the DWS was meant to capture but is not reported as such by workers. A more comprehensive survey of job changes and the underlying circumstances is needed in order to understand the decline in long-term employment more fully. 


\section{Appendix I: The CPS Data on Employer Tenure}

At irregular intervals, the Census Bureau has appended mobility supplements to the January or February Current Population Surveys. The years in which they did so include 1951, 1963, 1966, 1968, 1973, 1978, 1981, 1983, 1987, 1991, and in even years from 1996-2008. These supplements contain information on how long workers have been continuously employed by their current employer, and they are asked of all eight CPS rotation groups. However, only the supplements since 1973 are available in machine-readable form. Information on job durations is also available in pension and benefit supplements to the CPS in May of 1979, 1981, 1983, and 1988, and in April 1993. These supplements contain information on how long workers have been working for their current employer, and they are asked of four of the eight CPS rotation groups. Finally, information on job durations is available in the continuous and alternative employment arrangement supplements (CAEAS) to the CPS in February of 1995, 1997, 1999, 2001, and 2005. In total there are 22 CPS supplements with information on employer tenure available in machine readable form over the period from 1973 to 2008, and my analysis relies on these data.

A question of comparability of the data over time that must be kept in mind when interpreting the results arises because of a significant change in the wording of the central question about job duration. The early mobility supplements (1951-1981) asked workers what year they started working for their current employer. In later mobility supplements (1983-2008), in all of the pension and benefit supplements (1979-1993), and in all of the CAEAS supplements (1995-2005) workers were asked how many years they worked for their current employer. If the respondents were perfectly literal and accurate in their responses (a strong and unreasonable assumption), then these two questions would yield identical information (up to the error due to the fact that calendar years may not be perfectly aligned with the count of years since the worker started with his/her current employer). But responses are not completely accurate, and this is best illustrated by the heaping of responses at round numbers. The empirical distribution function has spikes at five-year intervals, and there are even larger spikes at ten-year intervals. In the early question, the spikes occur at round calendar years $(1960,1965$, etc.). Later, the spikes occur at round counts of years $(5,10,15$, etc.).

There are also subtle but potentially important changes in wording of the key questions even within these surveys. All of the mobility supplements since 1983 ask individuals how long they have worked continuously (italics added) for their current employer. However, neither the pension and benefit supplements nor the CAEAS include the word "continuously". The May 1979 and 1983 pension and benefit supplements ask individuals how long they have worked for their current employer and specify that if there was an interruption greater than one year to count only the time since the interruption. The May 1988 and April 1993 supplements and the CAEAS ask individuals how long they have worked for their current employer without any reference to interruptions or continuity. Thus, it might be the case that the mobility supplements would yield shorter tenures than the pension and benefit supplements and the CAEAS due to the requirement of continuity in the former. And it 
might be the case that the early two pension and benefit supplements would yield shorter durations than the later two pension and benefit supplements due to the consideration of long interruptions given in the early supplements. I make no explicit allowance for these differences in my analysis, but they should be kept in mind when interpreting the results.

With the exception of jobs of less than one year, all of the supplements before the February 1996 mobility supplement collect data on job duration in integer form reporting the number of years employed. For jobs of less than one year, the mobility supplements report the number of months employed while the pension and benefit supplements report only the fact that the job was less than one year old. The February 1996 and later mobility supplement ask workers how long they have worked continuously for their current employer and accepts a numerical response where the worker specifies the time units. The 1995-2005 CAEAS ask workers how long they have worked for their current employer and accepts a numerical response where the worker specifies the time units. Virtually all workers in jobs even five years old and all workers in jobs 10 years old or longer, report job durations in years.

One reasonable interpretation of the integer report of the number of years is that workers round to the nearest integer when they report jobs of duration of at least one year. ${ }^{22}$ For example, a response of 10 years would imply tenure greater than or equal to 9.5 years and less than 10.5 years. In order to create a smooth tenure variable, I assume that the distribution of job tenure is uniform in these one-year intervals. Given a reported tenure of $T$ years, I replace $T$ by $T-0.5+u$ where $u$ is a random variable distributed uniformly on the unit interval. $^{23}$

My sample consists of 924,423 not self employed workers aged 20-64 from the 22 CPS supplements covering the period from 1973 to 2008. The self-employed are not included because the concept of employer tenure is less clear for the self-employed, and, in any case, the CPS supplements do not contain consistent information on tenure for the self-employed.

\footnotetext{
22 This ignores the heaping of the tenure distribution at multiples of five and ten years.

23 Where reported tenure is zero years, I assume that tenure is uniformly distributed between zero and one and define tenure as $u$. Given that jobs are more likely to end earlier in the first year than later in the first year, this is not completely accurate (Farber, 1994). However, the measures used in my analysis will not be affected by this representation. Where reported tenure is exactly one year, I assume that true tenure is uniformly distributed between 1 and 1.5 and define tenure as $1+u / 2$.
} 


\section{$7 \quad$ References}

Burdett, Kenneth. "Employee Search and Quits," American Economic Review 68 (1978): $212-220$.

Diebold, Francis X., David Neumark, and Daniel Polsky. "Job Stability in the United States," National Bureau of Economic Research, Working Paper No. 4859, September 1994.

Diebold, Francis X., David Neumark, and Daniel Polsky. "Comment of Kenneth A. Swinnerton and Howard Wial, 'Is Job Stability Declining in the U.S. Economy?'," Industrial and Labor Relations Review 49 (January 1996) : pp. 348-352.

Farber, Henry S. "The Incidence and Costs of Job Loss: 1982-91," Brookings Papers on Economic Activity: Microeconomics, (1993,1), 73-119.

Farber, Henry S. "The Analysis of Inter-Firm Worker Mobility," Journal of Labor Economics, October 1994: pp. 554-593.

Farber, Henry S. "The Changing Face of Job Loss in the United States, 1981-1995," Brookings Papers on Economic Activity: Microeconomics, 1997: 55-128.

Farber, Henry S. "Are Lifetime Jobs Disappearing: Job Duration in the United States, 197393," in Labor Statistics Measurement Issues, John Haltiwanger, Marilyn Manser, and Robert Topel, eds., University of Chicago Press, 1998. pp. 157-203.

Farber, Henry S. "Has the Rate of Job Loss Increased in the Nineties?" Proceedings of the Fiftieth Annual Winter Meeting of the Industrial Relations Research Association, Volume 1, 1998: pp. 88-97.

Farber, Henry S. "Mobility and Stability: The Dynamics of Job Change in Labor Markets." In Ashenfelter and Card, eds. The Handbook of Labor Economics, vol 3B, pp. 24392484, North Holland Publishing Company, 1999.(a)

Farber, Henry S. "Alternative and Part-Time Employment Arrangements as a Response to Job Loss," Journal of Labor Economics 17 (October 1999): pp. S142-S169. (b)

Farber, Henry S. "Job Loss in the United States, 1981-2001," Research in Labor Economics 23 (2004), pp. 69-117.

Farber, Henry S. "What do we know about Job Loss in the United States? Evidence from the Displaced Workers Survey, 1981-2004," Economic Perspectives, Federal Reserve Bank of Chicago (Second Quarter, 2005), pp. 13-28. 
Farber, Henry S. "Is the Company Man an Anachronism? Trends in Long-Term Employment in the U.S., 1973-2006," in Danziger and Rouse, eds. The Price of Indenpendence, Russell Sage, 2007, pp. 56-83

Gardner, Jennifer M. "Worker Displacement: A Decade of Change," Monthly Labor Review 118 (April 1995): pp. 45-57.

Hipple, Steven. "Worker Displacement in the mid-1990's," Monthly Labor Review 122 (July 1999): pp. 15-32.

Jovanovic, Boyan. "Job Matching and the Theory of Turnover", Journal of Political Economy, 87 (1979), 972-990.

Kletzer, Lori G. "Returns to Seniority after Permanent Job Loss," American Economic Review 79 (June 1989): pp. 536-543.

Neal, Derek. "Industry-Specific Capital: Evidence from Displaced Workers," Journal of Labor Economics 13 (October 1995): pp. 653-677.

Parent, Daniel. "Industry-Specific Capital: Evidence from the NLSY and the PSID," Working Paper No. 350, Industrial Relations Section, Princeton University, November 1995.

Podgursky, Michael and Paul Swaim. "Job Displacement Earnings Loss: Evidence from the Displaced Worker Survey,"” Industrial and Labor Relations Review 41 (October 1987): pp. 17-29.

Gottschalk, Peter and Robert Moffitt. "Changes in Job Instability and Insecurity using Monthly Survey Data," "Has Job Stability Declined Yet? New Evidence for the 1990s," Journal of Labor Economics. 17:4, part 2 (October 1999): S91-S126.

Hall, Robert E. "The Importance of Lifetime Jobs in the U.S. Economy," American Economic Review 72 (September 1982): pp. 716-724.

Jaeger, David A. and Ann Huff Stevens. "Is Job Stability in the United States Falling? Reconciling Trends in the Current Population Survey and Panel Study of Income Dynamics," Journal of Labor Economics. 17:4, part 2 (October 1999): S1-S28.

Neumark, David, ed. On the Job: Is Long-Term Employment a Thing of the Past? New York. Russell Sage Foundation, 2000.

Neumark, David, Daniel Polsky, and Daniel Hansen "Has Job Stability Declined Yet? New Evidence for the 1990s," Journal of Labor Economics. 17:4, part 2 (October 1999): S29-S64. 
Rose, Stephen J. "Declining Job Security and the Professionalization of Opportunity," National Commission for Employment Policy, Research Report 95-04, April 1995.

Stevens, Ann Huff. "The More Things Change the More They Stay the Same: Trends in Long-term Employment in the United States, 1969-2002." NBER Working Paper No. 11878, December 2005.

Stewart, Jay. "Recent Trends in Job Stability and Job Security: Evidence from the March CPS," Bureau of Labor Statistics Working Paper No. 356, March 2002.

Swinnerton, Kenneth and Howard Wial. "Is Job Stability Declining in the U.S. Economy?" Industrial and Labor Relations Review 48 January 1995 : pp. 293-304.

Swinnerton, Kenneth and Howard Wial. "Is Job Stability Declining in the U.S. Economy? Reply to Diebold, Neumark, and Polsky" Industrial and Labor Relations Review 49 January 1996 : pp. 352-355.

Ureta, Manuelita. "The Importance of Lifetime Jobs in the U.S. Economy, Revisited," American Economic Review 82 (March 1992): pp. 322-335.

Valletta, Robert. "Declining Job Security," Journal of Labor Economics. 17:4, part 2 (October 1999): S170-S197. 